\title{
THE PROSODIC PHRASING OF PARENTHETICAL COMMENT CLAUSES IN SPONTANEOUS SPOKEN LANGUAGE: EVIDENCE FROM ICELANDIC HELD ÉG*
}

\author{
Nicole Dehé
}

\begin{abstract}
Based on the analysis of corpus data, this paper investigates the prosodic phrasing of the Icelandic parenthetical comment clause (CC) held ég ("believe/ think I'; I think, I believe) and relates the results to current prosodic theory. The main findings are as follows. (i) A variety of intonational phrasing patterns is possible with CC held ég, allowing both for prosodic separation such that the $\mathrm{CC}$ is phrased in its own Intonational Phrase (IP), and prosodic integration, such that the $\mathrm{CC}$ is phrased in one IP with surrounding material. (ii) Prosodic integration is by far the more common pattern. (iii) The prosodic phrasing of CCs is related to their meaning via prominence. In particular, CCs which can be argued to have conventional implicatures $(\mathrm{CI})$ semantics are prosodically prominent and phrased separately; CCs whose primary function is one of mitigation are unstressed and integrated. (iv) The observed intonational phrasing patterns can be accounted for in terms of the interaction of the syntax-prosody interface constraint MATCH CLAUSE with prosodic markedness constraints.
\end{abstract}

\section{Background and hypotheses}

\subsection{The prosodic phrasing of parenthetical comment clauses}

This paper analyses the prosodic phrasing of the Icelandic parenthetical comment clause (CC) held ég ('believe/think I'; I think, I believe), pronounced ['helt.jex] in its citation form, and discusses the findings in terms of prosodic theory, specifically the interaction of syntax-prosody interface constraints with prosodic markedness constraints. The meaning and use of Icelandic held ég is similar to English I think, I believe and German glaub ich (see (1)), and like CCs in German and Dutch, Icelandic held ég is verb-initial.

*I am grateful to Jóhannes Gísli Jónsson, who brought the whole point of Icelandic held ég being a good test case for the intonational phrasing of CCs to my attention, to Ásta Svavarsdóttir for giving me access to sound files which are not yet available online, and to Ingo Feldhausen for discussion. I would also like to thank Sigrún Gunnarsdóttir for careful segmental annotation and Kristján Árnason for double-checking on some of the tonal annotations and transcriptions. Thanks are also due to two anonymous reviewers for their comments. The results were presented at the $28^{\text {th }}$ Rask conference (Reykjavík, 25 January 2014), the 2014 LAGB conference (Oxford, UK, September 2014), as well as at HU Berlin (October 2014) and the University of Frankfurt (January 2015) and I would like to thank the respective audiences for valuable comments. This piece of research was supported by a Snorri Sturluson Fellowship from the Árni Magnússon Institute for Icelandic Studies to the author. 
(1) Sentence-medial comment clauses (CCs)

a. John arrived I think/believe later than Mary.

b. John ist glaub(e) ich später als Maria

John is think I later than Mary angekommen.

(German)

arrived

c. Jón kom held ég seinna en María. John arrived think I later than Mary

(Icelandic)

In the present study, sentence- or utterance-final CCs (e.g. (2)) as well as clause-internal ones (e.g. (3)) are considered. A typical non-final position in the present data set is between copula and following phrase (e.g. (3)a). Other non-final positions were, for example, between head and complement (see e.g. (3)b for a CC positioned between verbal head and complement) and within the verbal complex (see (3)c).

(2) CC held ég in final position (Source: Talmál, Samtöl ÍSTAL) ${ }^{1}$

já sko hann er níutíuogprjú held ég

yes so he is ninety-three think I

'Yes, he is ninety-three, I think'

(3) CC held ég in non-final position (Source: Talmál, Samtöl ungs folks

$(\mathrm{a}, \mathrm{c})$ and Samtöl ÍSTAL (b))

a. já pað væri held ég ágætis svona

yes it would.be think I fine such

'Yes, I think this would be fine [unfinished]'

b. ... hann er búinn аð eyða held ég ja yfir eitthvað he is finished to spend think I Part over something yfir fjögurhundruðpúsundkallinn

over four.hundred.thousand.crowns

'He has spent, I think, more than four hundred thousand crowns.'

c. ... peir eru held ég búnir að framlengja sko ... they are think I finished to extend so

'They have, I think, extended [Obj], so ...'

From a semantic-pragmatic point of view, CCs of the kind under discussion here have often been argued to attach an illocutionary commitment to an utterance or to serve metalinguistic functions, rather than contributing to the truth-conditionality of the host utterance (e.g., Urmson 1952, Hand 1993). CCs may function as mitigators, i.e. they are used to modify, correct, reinforce or soften a speech act performed by the host utterance (e.g. Mittwoch 1979, Fraser 1980, Quirk, Greenbaum et al. 1985, Schneider 2007a,b, Kaltenböck 2010). Since functions like these can also be achieved by message-oriented or attitudinal adverbs, CCs have been treated as epistemic adverbials,

\footnotetext{
${ }^{1}$ See Section 2 below for details on the corpora used in this study.
} 
pragmatic markers and discourse markers in the literature (e.g. Thompson \& Mulac 1991, Murphy 1993, Aijmer 1997, Kärkkäinen 2003, Brinton 2008, Dehé \& Wichmann 2010). Rooryck (2001) lists a range of evidential meanings expressed by CCs. Given their evidential meaning, Scheffler (2009) proposes a two-dimensional semantics for CCs. In her view, their main semantic contribution is to lower the epistemic threshold, which determines whether the speaker is sure of the proposition; their secondary contribution is to contribute a side comment in the domain of conventional implicatures (CIs): the actual content of the verb (e.g. think). Potts (2005:92) maintains that elements such as CC it seems and generally Ross' (1973) slifting constructions as well as question tags (isn't he) are parentheticals (or: supplements in his terminology) syntactically and that, like other types of parentheticals such as as-parentheticals and appositions, they are "intonationally isolated". Semantically, however, they are different from other types of parentheticals. In particular, Potts maintains that $\mathrm{CCs}$ and question tags affect the "at-issue core" of the utterance, thus they cannot be removed without affecting the main proposition. With respect to the relation between prosody and a two-dimensional semantics for CCs à la Scheffler, Dehé (2014) suggests that CCs whose function it is to affect the epistemic threshold and which have a polite, mitigating effect are typically without prominence and thus prosodically integrated; being without their own nuclear accent, they cannot be phrased in an Intonational Phrase of their own. CCs which have CI semantics, on the other hand, are typically prosodically prominent and phrased separately (see also Dehé \& Wichmann 2010 for related ideas). However, no formal analysis of the relation between prosody and meaning is offered in these works.

I assume that non-initial CCs of the kind under discussion here are main clause parentheticals syntactically (see most recently Griffiths 2015). They differ from their sentence-initial counterparts (as given in (4)) in a number of significant ways. For example, in languages such as German, Dutch and Icelandic, CCs have obligatory subject-verb inversion (see (5); Dutch example from Griffiths 2015:200). Kluck \& de Vries (2015) assume an operator object to the CC verb, which originates in the postverbal position and ends up in the pre-subject position as a result of movement (see (6)). This operator is co-referential with the host clause and may be null or spelled out as $z o / s o$ in Dutch and German, respectively (e.g. (7), Dutch example from Kluck \& de Vries 2015); see also the discussions in Reis (1995, 2002), Fortmann (2007) and Steinbach (2007) for German. Following this analysis, it is impossible for non-initial CCs to be the result of a movement operation taking sentences such as (4) as input. It has also been noted that sentences containing I think and related elements in initial vs. non-initial position are not paraphrases of each other 
semantically (e.g. Jackendoff 1972, Quirk, Greenbaum et al. 1985 for English).

(4) a. I think/believe John arrived later than Mary.

b. Ich glaube, John ist später als Maria

I believe John is later than Mary angekommen.

(German) arrived

'I think John arrived later than Mary.'

b'. Ich glaube, dass John später als Maria angekommen ist.

I believe that John later than Mary arrived is

'I think that John arrived later than Mary.'

c. Ég held að Jón hafi komið seinna en

I think that John has arrived later than María.

Mary

'I think that John arrived later than Mary.'

(5) Obligatory subject-verb inversion in non-initial CCs

a. Josef ist glaube ich / *ich glaube schon wieder zu

Josef is think I I think already again too spät.

(German)

late

'John is, I think, late again.'

b. Ik heb beken $i k / * i k$ beken, niet echt een

I have confess I I confess not really an mening.

(Dutch) opinion

'I don't really have, I confess, an opinion.'

c. Jón kom held ég / *ég held seinna en

John arrived think I I think later than

María.

Mary

(Icelandic)

(6) Syntactic analysis of CCs according to Kluck \& de Vries (2015)

$\mathrm{Bob},\left[\mathrm{OP}_{\mathrm{i}} / \mathrm{ZO}_{\mathrm{i}}\right.$ vermoed $\left.i k \mathrm{t}_{\mathrm{i}}\right]$, kent Bea goed.

Bob OP/so suspect I knows Bea well

(7) Object operator in preverbal position

a. Bob is, (zo) vermoed ik, een echte charmeur.

(Dutch)

Bob is (so) suspect I a real charmer

b. Tina, (so) glaube ich, möchte eine neue Theorie

Tina (so) believe I wants.to a new theory entwickeln.

(German) develop

'Tina, I believe, would like to develop a new theory.' 
Furthermore, as Griffiths (2015) shows, CCs behave like other types of parentheticals in that narrow syntax relations cannot be established between CC and host. For example, CCs are not within the scope of linearly preceding operators (e.g. negation in (8)), and they do not license binding dependencies which require c-command; see (9), both examples from Griffiths (2015:196). Notice that parentheticals of this kind are not subordinate clauses, either. For example, they are in the indicative unlike many embedded clauses in Icelandic, which are subjunctive (Thráinsson 1986:187).

(8) John won't be late, I reckon.

Interpretation: a. $\operatorname{reckon}(\mathrm{p}, \mathrm{I}) \wedge \neg[$ will-be-late(John)]

b. $* \neg[\operatorname{reckon}(p, \mathrm{I}) \wedge$ will-be-late $(\mathrm{John})]$

(9) a. *Who ${ }_{1}$ will John, $t_{1}$ thinks, be late?

b. John won't, \{everyone/*anyone\} thinks, be late.

c. Billy has, [every girl in the class $]_{\mathrm{i}}$ admits, a crush on her $\mathrm{r}_{\mathrm{k}} / *_{\mathrm{i}}$.

CCs are main clause parentheticals (ParP) adjoined to the host clause. The Par head and the CC are joined by parenthetical-merge (henceforth par-merge; de Vries 2007, 2012 and related work), which prevents elements in the host clause from c-commanding into the parenthetical. This is illustrated for the CC I think in (10), where dashed lines represent par-merge (adapted from Griffiths 2015:199).

(10) Par-merge of CCs

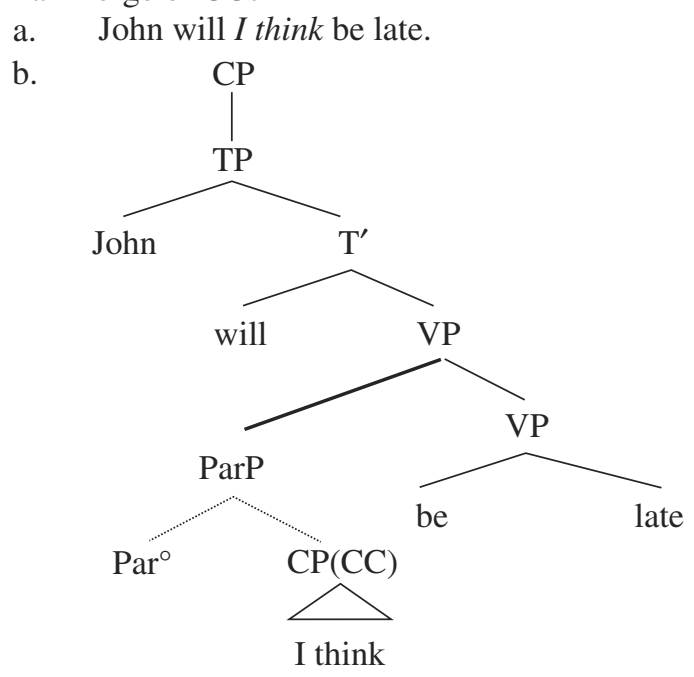

Given their clausal syntactic status as $\mathrm{CP}$ and their parenthetical relation with the host clause, CCs have often been assumed to be phrased in their own Intonational Phrase (IP) in the prosodic structure (e.g. Nespor \& 
Vogel 1986, Potts 2002, 2005, Truckenbrodt 2005, Brinton 2008 among others). Also, current prosodic Match theory (Selkirk 2009, 2011; see (11)), predicts for a clause in syntactic constituent structure to be matched by an IP in prosodic structure, thus predicting prosodic separation of the CC in either a non-recursive (see (12)a) or a recursive (see (12)b, c) prosodic structure, depending on what kind of syntactic constituent precedes and follows the CC in the linear structure (see also Dehé 2014). (In (12) and elsewhere below, optional material is indicated by left and right arrowheads $<>$ to avoid confusion.)

(11) Match theory (from Selkirk 2009:40, 2011:439)

(i) Match clause

A clause in syntactic constituent structure must be matched by a corresponding prosodic constituent (i.e., the IP) in phonological representation.

(ii) Match phrase

A phrase in syntactic constituent structure must be matched by a corresponding prosodic constituent (i.e., the phonological phrase) in phonological representation.

(iii) MATCH WORD

A word in syntactic constituent structure must be matched by a corresponding prosodic constituent (i.e., the prosodic word) in phonological representation.

(12) Prosodic phrasing of CCs as predicted by Match Clause

a. ${ }_{\text {IP }}(\text { clause } 1)_{\text {IP IP }}(\mathrm{CC})_{\text {IP }}<{ }_{\text {IP }}(\text { clause } 2)_{I P}>$

b. ${ }_{\text {IP }}\left(\mathrm{XP} 1_{\text {IP }}(\mathrm{CC})_{\text {IP }} \mathrm{XP} 2\right)_{\text {IP }}$

c. ${ }_{\text {IP }}\left(\mathrm{PWd}{ }_{\text {IP }}(\mathrm{CC})_{\mathrm{IP}} \ldots\right)_{\mathrm{IP}}$

However, careful prosodic analysis of English CCs has shown that it is prosodic integration rather than separation that is the most common pattern of prosodic phrasing for CCs in actual spoken language. In other words, CCs are commonly phrased together with surrounding host material in one prosodic domain, yielding structures as in (13)c-e; see e.g. the corpus studies by Dehé (2009a), Dehé \& Wichmann (2010), and Dehé (2014), confirming earlier assumptions for English by e.g. Crystal (1969), Bing (1985) and Gussenhoven (2004). In particular, these results show that CCs are commonly tonally integrated as prenuclear or postnuclear material without a nuclear (or even non-nuclear) accent of their own. In Dehé's (2014: Chapter 4) analysis based on data from the spoken part of the British Component of the International Corpus of English (ICE-GB), the two prosodic phrasing patterns in (13)c and (13)e together accounted for $67 \%$ of the CCs analysed $(100 \%: \mathrm{N}=147)$, while separation as in (13)a and (13)b accounted for only $18 \%$ and 5\%, respectively. In Peters' (2006) corpus study on the prosodic phrasing of parentheticals in German $(\mathrm{N}=96)$, on the other hand, the pattern equivalent to (13)b was 
most prominent $(>40 \%)$ and prosodic incorporation corresponding to (13)e was the least frequent pattern $(<10 \%)$. However, while Peters (2006) does not give details about the types and distribution of the parentheticals that made up his data set, he reports that there is a relation between prosodic structure and size of parenthetical such that shorter parentheticals (i.e., fewer syllables) are more likely to be integrated than longer ones. This in turn is not fully in line with Dehé's (2014) extensive corpus study on English, where question tags are phrased in a separate IP much more frequently than CCs, suggesting that if length affects phrasing, it may be overridden by other factors. Crucially in the present context, phrasing of CCs together with host material is common in languages which have undergone empirical prosodic research, and separation as given in (13)a and b, despite being assumed in much of the theoretical literature, represents the minority of cases in actual spoken language.

(13) Observed prosodic phrasing of CCs in English; from Dehé (2014:176) ${ }^{2}$ Prosodic separation:

$$
\begin{aligned}
& \text { a. } \left.\ldots \operatorname{IP}_{\mathrm{IP}}(\ldots)_{\mathrm{IP}} \operatorname{IP}(\mathrm{CC})_{\mathrm{IP}} \operatorname{IP}(\ldots)_{\mathrm{IP}} \ldots \quad 27 \text { (out of } 147\right) \mathrm{CCs}(18 \%) \\
& \text { b. } \ldots \operatorname{IP}\left(\cdots \operatorname{IP}(\mathrm{CC})_{\mathrm{IP}} \ldots\right)_{\mathrm{IP}} \ldots \quad 8 \text { (out of } 147 \text { ) CCs }(5 \%) \\
& \text { Prosodic integration: } \\
& \text { c. } \left.\ldots \operatorname{IP}(\ldots)_{\mathrm{IP}} \operatorname{IP}(\ldots \mathrm{CC})_{\mathrm{IP}} \operatorname{IP}(\ldots)_{\mathrm{IP}} \ldots \quad 45 \text { (out of } 147\right) \mathrm{CCs}(31 \%) \\
& \text { d. } \left.\ldots \operatorname{IP}_{\operatorname{IP}}(\ldots)_{\operatorname{IP}} \operatorname{IP}(\mathrm{CC} \ldots)_{\mathrm{IP}} \operatorname{IP}(\ldots)_{\operatorname{IP}} \ldots \quad 9 \text { (out of } 147\right) \text { CCs }(6 \%) \\
& \text { e. } \left.\ldots \operatorname{IP}(\ldots)_{\operatorname{IP}} \operatorname{IP}(\ldots \mathrm{CC} \ldots)_{\operatorname{IP}} \operatorname{IP}(\ldots)_{\operatorname{IP}} \ldots 53 \text { (out of } 147\right) \operatorname{CCs}(36 \%)
\end{aligned}
$$

Given that Match constraints are violable interface constraints in competition with other constraints (Selkirk 2009, 2011), prosodic phrasing violating Match should follow from the possibility of other constraints outranking Match. Selkirk (2011:468-472), for example, discusses prosodic markedness constraints such as size constraints, leftedge strengthening and prosodic stress prominence assignment. In previous work on English CCs (Dehé 2009a, 2014), these constraints have not been taken into account; instead prosodic integration has been accounted for in terms of restructuring in Nespor \& Vogel's (1986) sense, considering factors such as prosodic constituent size, speech rate and pragmatic function of the CC. Prosodic separation as in (13)a, where it does not follow from Match Clause (e.g. because the constituent preceding CC is a prosodic phrase or word rather than an IP) has been vaguely put down to promotion of a lower-level prosodic boundary to a higher-level one, but again without relating to prosodic markedness constraints. For example, Myrberg's (2013) constraint Equal Sisters, demanding for sister nodes in prosodic structure to be instantiations of the same prosodic category, may account for the

\footnotetext{
${ }^{2}$ The prosodic phrasing of five out of 147 CCs (4\%) remained unclear after careful analysis by three annotators, adding up to 147 tokens $(100 \%)$.
} 
promotion; this has not previously been thought through for the phrasing of CCs.

To add another language, to further test the intonational phrasing of $\mathrm{CCs}$, and to provide a first account in terms of the interaction of syntaxphonology interface constraints and prosodic markedness constraints, the present paper studies the Icelandic CC held ég.

\subsection{Cues to IP-boundaries in Icelandic}

Previous work in Icelandic prosody has identified tonal and segmental cues to Intonational Phrase (IP) boundaries in this language. First, tonal cues include the presence of at least one pitch accent and a boundary tone. If there is more than one pitch accent in one IP, one of them is nuclear. This is typically the final one because phrase-level and sentencelevel stress in Icelandic is rightmost (Árnason 1998 among others). The Icelandic tonal inventory has two boundary tones: $\mathrm{L} \%$ and $\mathrm{H} \%$ (Árnason 1998, 2005, 2011, Dehé 2009b). Moreover, in Icelandic the IP is the domain for downstep; pitch reset can be observed at the beginning of a new IP (Árnason 1998, 2011, Dehé 2009b). An example is given in (14)/Figure $1 .^{3}$ The utterance is made up of two IPs as indicated in (14)b. The first IP is terminated by $\mathrm{H} \%$ indicating non-finality, the second by $\mathrm{L} \%$. Both IPs are also the domain of downstep, such that the pitch peak associated with the first syllable of Sigurður $(281 \mathrm{~Hz})$ in IP1 is lower than the one associated with the first syllable of Siggi $(314 \mathrm{~Hz})$, and the pitch peak associated with the first syllable of Kristin $(260 \mathrm{~Hz})$ in IP2 is lower than the one associated with the first syllable of Stina $(297 \mathrm{~Hz})$. Pitch reset can be observed in IP2 such that the pitch peak associated with the first syllable of Stina is reset as compared to the peak associated with Sigurður in IP1. Overall, the pitch level in IP2 is slightly lower than in IP1. In this particular example, the two IPs are also separated by a pause of 240 milliseconds $(<$ SIL $>$ in Figure 1).

(14) a. Siggi heitir auðvitað Sigurður, en Stína heitir Kristín. Siggi is.called of.course Sigurður and Stína is.called Kristín 'Siggi's real name is of course Sigurður, and Stína's name is Kristín.'

b. IP1 $[\text { Siggi heitir auðvitað Sigurður }]_{\text {IP1 IP2 }}[\text { en Stína heitir Kristín }]_{\text {IP2 }}$

\footnotetext{
3 The example in (14)/Figure 1 is taken from the Siggi og Stina data set, which is based on a recording of the Icelandic children's story Siggi og Stina. The version used here was originally tape-recorded for use as a comprehension exercise in foreign language teaching. It was read and recorded by a trained female speaker in a colloquial way. At the time of the recording, the speaker did not know that it would be used for any other purpose than her intended one. The recording was digitised into individual sound files for the purpose of linguistic analysis. Selected utterances were also used in Dehé (2008, 2009b); examples (17)c and (19) below, taken from Dehé (2008), are also from this data set.
} 


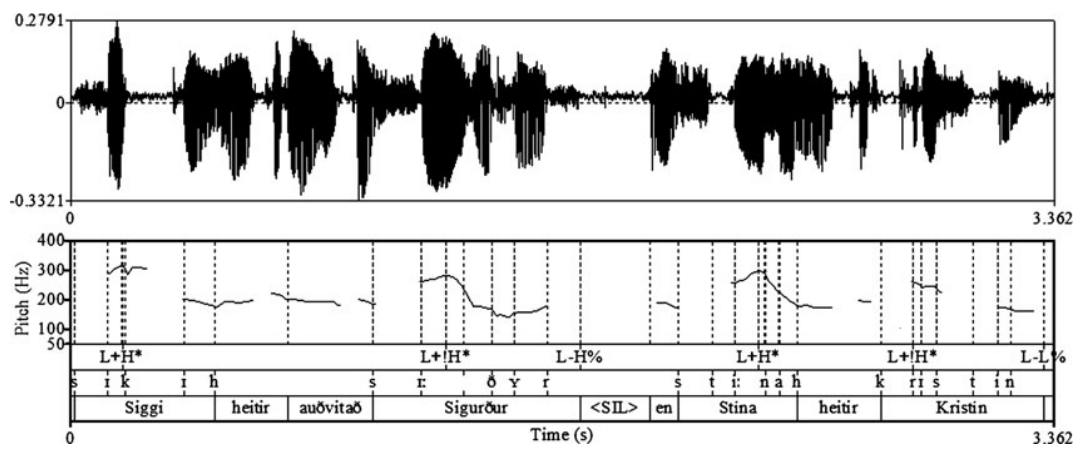

Figure 1. Utterance (see example (14)) made up of two IPs, signalled by $\mathrm{H} \%$ terminating IP1, downstep within IPs, and pitch reset at the beginning of IP2.

Second, Icelandic has a number of segmental processes which (frequently though not obligatorily) occur in connected speech, but not across IP boundaries. In other words, even if these processes are optional to a certain extent, their application clearly indicates the lack of an IP-boundary. Particularly relevant in the present context are word-initial $/ \mathrm{h} /$-dropping and word-final vowel deletion. In Icelandic connected speech, a word-initial glottal fricative $/ \mathrm{h} /$ such as the initial $/ \mathrm{h} /$ on held in the $\mathrm{CC}$ held ég may be dropped. This has been described for pronoun cliticisation (Árnason 2009, 2011), see (15), and it also follows from phonetic transcriptions such as those given in (16). If $/ \mathrm{h} /$-dropping results in a sequence of two vowels, there may be word-final vowel deletion on the preceding word. The sequence treysti honum in (15) is pronounced such that the initial /h/ on honum and the preceding word-final vowel / I/ on treysti are both dropped, as illustrated by the transcription. In (16), the word-final $/ \mathrm{r} /$ of for $r$ has been resyllabified as onset of the following syllable after $/ \mathrm{h} /$-dropping.

(15) Pronoun cliticisation involving /h/-dropping (Árnason 2009:287,

2011:263)

Ég treysti honum ekki ['threistonum]

I trust him not

'I don't trust him'

(16) /h/-dropping in connected speech (Árnason 2011:293)

Jón fór heim

John went home

['jouṽfou'rei:m]

'John went home' 
Icelandic word-final vowel deletion (FVD) is a process which deletes word-final vowels before initial vowels on the next word (Einarsson 1973, Árnason 1980, 2011, Helgason 1993, Dehé 2008). It is a common process, which, according to Árnason (1980:219), also occurs in formal styles. ${ }^{4}$ However, the process has been found to be prosodically constrained such that it is affected by prosodic phrasing along with focal emphasis and eurhythmy (Dehé 2008). Specifically, Dehé (2008) argues that FVD is obligatorily blocked at the right edge of an IP-boundary (see (17)a), which is also the domain for rhythmic adjustments. Within IP, FVD is not obligatory but it is common, and it is most frequent within a syntactic XP (see (17)c), and significantly less frequent at syntactic XPedges (see (17)b; in (17), underlining marks the relevant vowels; parentheses around vowels indicate the option of FVD). In (17)a, deletion of the final vowels on barninu and konunni is blocked despite being followed by an initial vowel on the following word. This is because an IP-boundary intervenes, indicated here by the comma in writing. In (17)b the final vowel on Jónina and the initial vowel on the next word are within the same IP, thus FVD is possible and probably favoured because it results in a regular rhythmic pattern. In (17)c, FVD is likely to occur given that borgina and okkar are in the same prosodic and syntactic phrase and deletion would result in a regular trochee within the phrase yfir borgin (a) okkar. FVD is also possible if the word which loses a vowel is reduced to one syllable (see (18) and pronoun cliticisation in (15)), regardless of whether the reduced word is a lexical or a functional category, and it may also occur if the affected word is reduced to nonsyllabic status (see the attested example in (19)). ${ }^{5}$ In (18)b, notice the palatalisation of the final vowel of $e k k i$, which is /I/ in citation form, instead of deletion.

(17) Final vowel deletion; examples from Dehé (2008)

a. Auður hjálpaði barninu, Anna hjálpaði konnuni, Elísabet Auður helped the.child Anna helped the.woman E.

hjálpaði lækninum.

helped the.doctor

b. Jónín(a) eldar ekki fisk.

Jónína cooks not fish

'Jónína does not cook fish'

c. Heðan sjáum við vel yfir borgin(a) okkar.

From.here see.1.Pl. we well over town.ACC.Sg.def our

'From here we have a good view over our town.'

\footnotetext{
${ }^{4}$ Árnason (2009:294-295, 2011:296) reports that FVD does not apply to the vowels /i/, $/ \propto /$ and $/ \mathrm{o} /$.

${ }^{5}$ Note that orthographic $<\dot{\mathrm{u}}>$ as in $n u ́$ corresponds to $/ \mathrm{u}: /$, while orthographic $<\mathrm{u}>$ as in upp corresponds to $/ \mathrm{Y} /$, thus deletion here cannot be put down to a sequence of identical vowel, as a reviewer suggests.
} 
(18) Final vowel deletion; examples and transcriptions of relevant sequences from Einarsson (1973:27)
a. Ekki er að tala um pað.
Not is to talk about it
'No need to discuss that'
b. Ertu ekki enn búinn? [ $\left.\varepsilon_{\circ}^{r} \cdot t \varepsilon^{\mathrm{h}} \mathrm{k}_{\mathrm{j}} \varepsilon \mathrm{n}^{\prime}\right]$ are.you not yet ready

(19) Final vowel deletion on a mono-syllabic word; example from Dehé (2008:741)

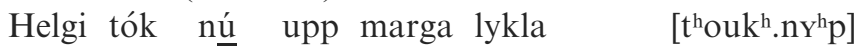
Helgi took now up many keys

If an IP-boundary intervenes between held ég and the preceding word, $/ \mathrm{h} /$-dropping and FVD are blocked. If there is no IP-boundary in this position, both processes are free to apply.

\subsection{Hypotheses}

Against the background outlined in the sections above, the hypotheses in (20) will be tested.

(20) Hypotheses

I: Like English CCs, Icelandic CCs exhibit a variety of intonational phrasing patterns (as identified on the basis of tonal and segmental cues).

II: The observed intonational phrasing patterns can be accounted for in terms of the interaction of the syntax-prosody interface constraint MATCH CLAUSE with prosodic markedness constraints.

III: Pragmatics is essential because CCs may or may not be prosodically prominent according to their meaning in context.

The intonational phrasings we predict to find largely correspond to the ones found for English given in (13) above. We predict that CCs may either be prosodically separate, i.e. phrased in their own prosodic domain associated with a nuclear accent of their own (see (13)a-b and (21)), or they may be prosodically integrated with host material, in which case they are typically realised without prominence (see (13)c-e/(24)). First, prosodic separation as given in (13)a-b and (21) and illustrated in (22) and (23) is in line with the interface constraint MATCH CLAUSE as given in (11)i. (Round brackets () indicate prosodic structure; square brackets [] indicate syntactic structure; left and right arrowheads $<>$ indicate optional material. ${ }^{6}(21) \mathrm{a}$,

\footnotetext{
${ }^{6}$ Notice that the patterns in (22) and (23), as well as in (25) through to (27), are example patterns. The actual, attested phrasings of these corpus examples may deviate from these illustrations.
} 
exemplified in (22), represents a non-recursive prosodic structure, which is predicted by MATCH CLAUSE for CCs in sentence-final position and for CCs wedged between two (e.g. coordinated) clauses. (21)b, illustrated in (23)b, represents a recursive prosodic structure, which is predicted by МАтсH CLAUSE if the syntactic string preceding the $\mathrm{CC}$ is not a clause, and if MATCH CLAUSE is not dominated by another constraint demanding prosodic sister constituents to be of the same prosodic category (EqualSisters; Myrberg 2013). A CC phrased in its own IP bears nuclear prominence; prominence may be associated with either the verb or the pronoun. The blocking of both / $\mathrm{h}$-dropping on held and FVD of the IP-final vowel (underlined in (22) and (23)), as well as relevant tonal events will serve as cues to the IPboundaries separating held ég from surrounding material.

(21) Prosodic phrasing of comment clause held ég: prosodic separation

a. ${ }_{\text {IP }}(\text { clause })_{\text {IP IP }}(\text { held ég })_{\text {IP }}<_{\text {IP }}(\text { clause })_{\text {IP }}>$

b. ${ }_{\mathrm{IP}}\left(\ldots \mathrm{IP}_{\mathrm{IP}}(\text { held ég })_{\mathrm{IP}} \ldots\right)_{\mathrm{IP}}$

(22) Prosodic phrasing of comment clause held ég: held ég phrased separately according to (21)a, following Match Clause (Source:

Talmál, Samtöl ÍSTAL)

a. CP$_{0}$ betta er allt sjálfboðavinna] ${ }_{\mathrm{CP}}[$ held ég $]$

That is all voluntary.work think I

b. IP(petta er allt sjálfboðavinna $)_{\mathrm{IP}} \mathrm{IP}(\text { held ég })_{\mathrm{IP}}$

(23) Prosodic phrasing of comment clause held ég: held ég phrased separately according to (21)b (Source: Talmál, Samtöl ungs fólks)

a. ${ }_{\text {cP }}\left[\right.$ bað eru ${ }_{\mathrm{CP}}\left[\right.$ held ég] mörg lönd ${ }_{\mathrm{CP}}[\mathrm{sem}$ purfa að

it are think I many countries that need to

líða fyrir pað]]

suffer for it

b. $\operatorname{IP}_{(\mathrm{p}}$ (bð eru ${ }_{\mathrm{IP}}(\text { held ég })_{\mathrm{IP}}$ mörg lönd $)_{\mathrm{IP}} \ldots$

Second, prosodic integration of held ég, i.e. phrasing of the CC together with host material in one IP (see (24) and the illustrations in (25) through to (27)), requires for MATCH CLAUSE to be violated and outranked by other (prosodic markedness) constraints. A CC phrased with host material in one IP is typically not associated with prominence. It makes up either postnuclear $((24) \mathrm{a} /(25) \mathrm{b}$; possibly also $(24) \mathrm{c}) /(27) \mathrm{b})$ or prenuclear $((24) b, c /(26) b,(27) b)$ material in its IP. The potential application of both / $\mathrm{h}$-dropping on held and FVD on the word-final vowel preceding held (underlined in the examples below) in (24)a,c, (25) and (27), and their absence in (24)b and (26), as well as relevant tonal events, will serve as cues to intonational phrasing. 
(24) Prosodic phrasing of comment clause held ég: prosodic integration a. $<_{\mathrm{IP}}(\ldots)_{\mathrm{IP}}>{ }_{\mathrm{IP}}(\ldots \text { held ég })_{\mathrm{IP}}<_{\mathrm{IP}}(\ldots)_{\mathrm{IP}}>$

b. $\operatorname{IP}_{\mathrm{IP}}(\ldots)_{\mathrm{IP}} \mathrm{IP}(\text { held ég } \ldots)_{\mathrm{IP}}<_{\mathrm{IP}}(\ldots)_{\mathrm{IP}}>$

c. $<_{\mathrm{IP}}(\ldots)_{\mathrm{IP}}>{ }_{\mathrm{IP}}(\ldots \text { held ég } \ldots)_{\mathrm{IP}}<_{\mathrm{IP}}(\ldots)_{\mathrm{IP}}>$

(25) Prosodic phrasing of comment clause held ég: held ég integrated according to (24)a, violating MATCH Clause (Source: Talmál, Samtöl ÍSTAL)

a. CP[petta er allt sjálfboðavinna] ${ }_{\mathrm{CP}}[$ held ég $]$

That is all voluntary.work think I

b. IP(betta er allt sjálfboðavinna held ég $)_{\mathrm{IP}}$

(26) Prosodic phrasing of comment clause held ég: held ég integrated according to (24)b, violating Match Clause (Source: Talmál, Samtöl ISTAL)

a. ${ }_{\mathrm{CP}}\left[\mathrm{pað}\right.$ eru ${ }_{\mathrm{CP}}\left[\right.$ held ég] mörg lönd ${ }_{\mathrm{CP}}[\mathrm{sem}$ purfa að it are think I many countries that need to líða fyrir pað]] suffer for it

b. IP (pað eru $)_{\text {IP IP }}$ (held ég mörg lönd $)_{I P} \ldots$

(27) Prosodic phrasing of comment clause held ég: held ég integrated according to (24)c, violating Match Clause (Source: NDC)

a. ${ }_{\mathrm{CP}}\left[E\right.$ Ég hef nú bara ${ }_{\mathrm{CP}}[$ held ég] einu sinni farið á I have now only think I once went skíði sko ...]

skiing so

b. IP(Ég hef nú bara held ég einu sinni farið á skíði sko) $)_{\mathrm{IP}}$

Pragmatics is essential (Hypothesis III in (20) above). If in its utterance the CC has CI semantics in Potts' (2005) sense, i.e. functions as a true side remark, it will have prominence. If, on the other hand, the CC's function is to lower the epistemic threshold (Scheffler's 2009 primary function), it will not be prominent. This is crucial because prominence affects intonational phrasing.

In order to test these hypotheses against the background laid out above, a corpus study was carried out and 47 instances of CC held ég as used in spontaneous spoken language entered the prosodic analysis. The results confirm the predicted variation (Hypothesis I in (20) above) in the intonational phrasing of $\mathrm{CC}$ held ég. Section 2 reports on the data sources for the analysis and data treatment, the analysis of held ég and the results. Section 3 discusses these results in light of current prosodic theory, addressing hypotheses (20)II and III. Section 4 is a short summary. 


\section{Materials, analysis and results}

The hypotheses formulated in (20) above were tested on the basis of a set of spontaneous spoken language data. To this end, two corpora were searched for held ég: Talmál and The Nordic Dialect Corpus (hereafter NDC). The Talmál is part of the MÍM corpus, a morphosyntactically tagged corpus of written and spoken Icelandic (Helgadóttir, Svavarsdóttir et al. 2012). ${ }^{7}$ The spoken part is made up of about 54 hours (approximately 500000 words) of natural speech, all recorded between 2000 and 2006, making up 2.2\% of the MíM corpus. It consists of four subparts (see Thráinsson, Angantýsson et al. 2007, Helgadóttir, Svavarsdóttir et al. 2012 for details): (i) the Alpingisumrceður (Parliament Speech Corpus) consists of recordings from unprepared/unscripted meetings in the Icelandic parliament recorded in the winter of 20042005; the (ii) Samtöl ÍSTAL and (iii) Samtöl ungs fólks parts consist of conversations of 2-6 participants recorded in informal settings such as work places or private homes; (iv) the Viðtöl part contains more formal interviews between one interviewer and three interviewees. The Talmál corpus is separately searchable for specific strings via the Lexis-Corpus web interface. ${ }^{8}$ The sound files of the Parliament Speech Corpus are accessible via its website. ${ }^{9}$ The sound files of three of the four parts of the Talmál, notably the sound files of the Parliament Speech Corpus and the two Samtöl parts of the corpus, were available for use in the present study.

The NDC (Johannessen, Priestley et al. 2009) contains data from Danish, Faroese, Icelandic, Norwegian and Swedish, but only the spoken Icelandic part (Thráinsson, Angantýsson et al. 2007) was searched for the purpose of this study. As of 2009, the corpus contained approximately 466000 words overall, 10287 Icelandic, but it has been growing since then, most recently in 2013 while the present study was conducted. The corpus is web-based and fully searchable and audio as well as video files may be downloaded. ${ }^{10}$

The two corpora are partly overlapping, because the Talmál also entered the NDC (see Thráinsson, Angantýsson et al. 2007). However, new recordings have been added to the NDC, thus in the present data set, nine instances of held ég were found in the NDC which were not part of the output of the Talmál search. Note that given the nature of the corpora, the data set extracted from them is a cross-section across different registers.

\footnotetext{
${ }^{7}$ http://mim.arnastofnun.is/ (last accessed 12 July 2016)

${ }^{8} \mathrm{http}: / /$ corpus.arnastofnun.is/ (last accessed 12 July 2016)

${ }^{9} \mathrm{http} / / /$ www.malfong.is/ (last accessed 12 July 2016)

${ }^{10} \mathrm{http}: / /$ www.tekstlab.uio.no/nota/scandiasyn/index.html (last accessed 12 July 2016)
} 
Both the Talmál and the Icelandic part of the NDC were searched for held, yielding 857 and 152 matches, respectively. These outputs were then submitted to manual sorting, such that (i) all items which were not held ég were removed, and (ii) all sequences of held preceded by a word ending in a vowel (V) were kept, all other sequences were removed in order to allow for segmental cues to IP-boundaries along with tonal cues. In a next step, only instances of held ég as a CC were considered, and all other items were discarded. Examples for items discarded under step (iii) are given in (28). The main criteria were syntactic ones: Icelandic being a verb-second language, non-CC items were mostly instances of held as main verb of the sentence, ending up in a position preceding its subject ég as a result of subject verb inversion due to a constituent other than the subject in initial position, e.g. adverbs or conjunctions (see (28)a-c), and occasionally topicalisation out of an embedded $a ð$ - ('that') clause (see (28)d). In addition, there were also uses of the verb að halda with lexical meaning other than 'think, believe' (see (28)e). Finally, (iv) all available sound files were retrieved and those items were discarded for which there was either no sound file available or the quality of the sound file was not good enough for auditory and/or instrumental analysis due to overlapping speech in the target area or too much background noise. Two of the remaining NDC items were also contained in the remaining Talmál set and (v) were therefore removed from the analysis. Table 1 summarises the steps of the manual sorting procedure and the numbers of instances of held ég remaining after each step. After the manual sorting, forty-seven instances of held ég entered the analysis.

Table 1. Manual sorting process after corpus search; $\mathrm{V}=$ vowel

\begin{tabular}{lll}
\hline & $\begin{array}{l}\text { Talmál: } \\
\text { instances of held } \\
\text { ég remaining }\end{array}$ & $\begin{array}{l}\text { The Nordic } \\
\text { Dialect Corpus: } \\
\text { instances of held } \\
\text { ég remaining }\end{array}$ \\
\hline $\begin{array}{ll}\text { input } \\
\text { (i) all instances of held } \text { other than }\end{array}$ & 857 & 152 \\
held ég removed & 242 & 57 \\
$\begin{array}{l}\text { (ii) reducing the set to V-held sequences } \\
\text { (iii) discarding all instances which were }\end{array}$ & 113 & 15 \\
not CCs & 59 & 15 \\
$\begin{array}{l}\text { (iv) accessibility and quality of sound files } \\
\text { (v) removing items present in both }\end{array}$ & 39 & 10 \\
data sets & 39 & 8 \\
output; items analysed overall & \multicolumn{2}{c}{$\mathbf{4 7}$} \\
\hline
\end{tabular}


(28) Examples of non-CC held ég discarded from the analysis (Source: Talmál, Samtöl ÍSTAL (a, e), Viðtöl (b, d), Alpingisumræður (c)) but now think I that it would.be naturally next ár sem skiptir mestu máli tíunda bekkur year that divide most case tenth class 'But now I think that it would naturally be the next year, which would be most important the tenth class'

b. náttúrlega held ég líka að sko próunin að hún naturally think I also that so development that she hafði líka rosalega mikið með petta að segja had also extremely much with that to say

'Naturally I think that the development played a big role'

c. pess vegna held ég að menn purfi nú ekki að therefore think I that men-Nom.Pl. need now not that deila mikið um pað að argue much about it that

'Therefore I think that people don't have to argue much about it'

d. hjá eldra fólki held ég að petta sé mjög with older people think I that that would.be very algengt common

'I think that that this would be very common with older people.' e. náttúrlega í tímum hjá mér pá hef ég eða pá held naturally in class at me then have I or then hold ég upp stífum aga I up stern discipline

'And of course in my class I have or I hold up strong discipline.'

\subsection{Data treatment and annotation}

The prosodic analysis of the 47 remaining instances of held ég was done in Praat (Boersma 2001, Boersma \& Weenink 2012) on the basis of careful inspection of the spectrogram and native speaker perception. The analysis comprised three tiers: a tonal tier for intonational analysis in terms of pitch accents and boundary tones, a segmental tier focusing on the segmental processes relevant here (i.e., /h/-dropping and FVD), and a text tier. The annotation was done by the author of this paper (mostly tonal tier and text tier) and by Sigrún Gunnarsdóttir (segmental tier and text tier), a native speaker of Icelandic, who is trained in phonetic annotation with a focus on Icelandic vowels (see Gunnarsdóttir 2012). Items for which the analysis was not immediately clear were given to another expert in Icelandic phonology. The tonal analysis focused on boundary tones to identify IP-boundaries, but all utterances were also 
annotated for pitch accents, following previous work on pitch accents and boundary tones in Icelandic (Árnason 1998, Dehé 2010). In particular, two bitonal pitch accents, $\mathrm{L}^{*}+\mathrm{H}$ and $\mathrm{L}^{+} \mathrm{H}^{*}$, have been identified for Icelandic (Dehé 2010). Note that a prosodic hierarchy has not yet been established and it cannot be done in this paper. However, as mentioned in Section 1.2 above, it has been observed that Icelandic has two boundary tones at IP level $(\mathrm{L} \%, \mathrm{H} \%)$ and that the IP is the domain for downstep (Árnason 1998, Dehé 2009b). There is preliminary evidence for a level between the IP and the prosodic word from the environment of FVD application (Dehé 2008), and preliminary evidence for phrase accents L- and T-, i.e. the edge tone of intermediate phrase (ip), in Dehé (2009b), but more systematic research is necessary. In the present study, boundaries are therefore annotated T-T\% (e.g., L-L\%) if they are clear IP-boundaries, and occasionally \# if they are clear boundaries above word level but can be ip or IP (see e.g. Figure 4 below). In determining prosodic separation, this work follows the definition of prosodic separation developed in Dehé (2014), which is given in (29) and crucially involves nuclear prominence associated with the prosodically separate constituent as well as tonal and other boundary cues (e.g. pauses) to its left and right.

(29) Prosodic separation (from Dehé 2014:103)

A segmental string (e.g. a parenthetical) is prosodically separate if it has a nuclear accent and is immediately preceded and followed by a phrasal prosodic boundary marked by edge tones along with other phonetic parameters marking the edge of a phrasal prosodic constituent.

The segmental analysis was straightforward. For each utterance containing held ég, the sequence <word1 word2> was segmentally annotated, with word 2 being held and word 1 being the word immediately preceding held. Two examples of the segmental analysis are given in Figure 2 and Figure 3, both by the same speaker, showing only held ég and the word preceding the CC. In Figure 2, as can be seen on the segmental tier plotted together with spectrogram and waveform, the initial glottal fricative $/ \mathrm{h} /$ on held is realised and the preceding vowel on abbey is clearly pronounced. In Figure 3, on the other hand, both /h/-dropping on held and FVD on the preceding word (here: bara) apply.

Ten further items had to be discarded because the quality of the sound file was not good enough for instrumental analysis, for example due to overlapping speech or bad recording quality, or because the actual utterance did not correspond to the corpus transcriptions such that no held ég was present in the utterance. The final data set was thus reduced to thirty-seven items. 


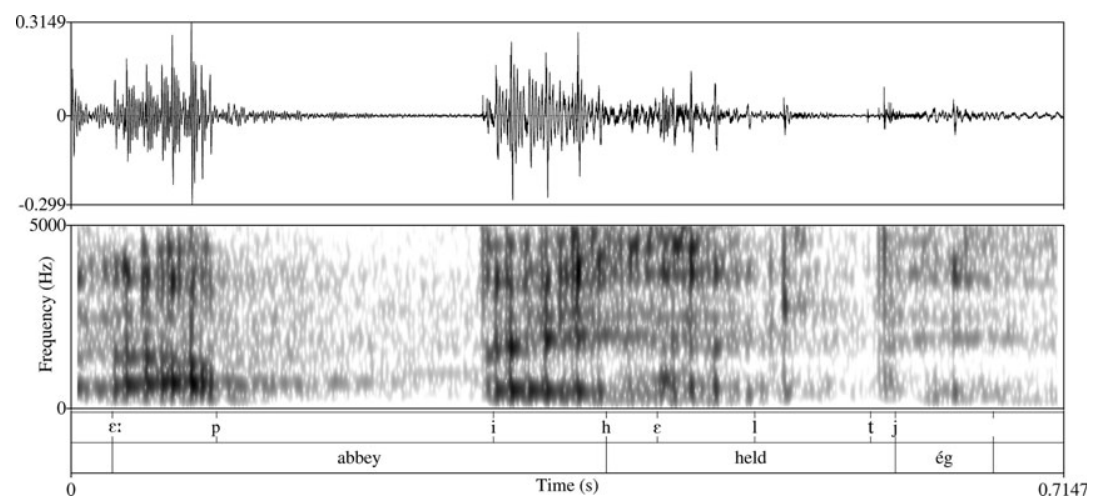

Figure 2. Target sequence: abbey held ég; no /h/-dropping on held, no FVD on abbey

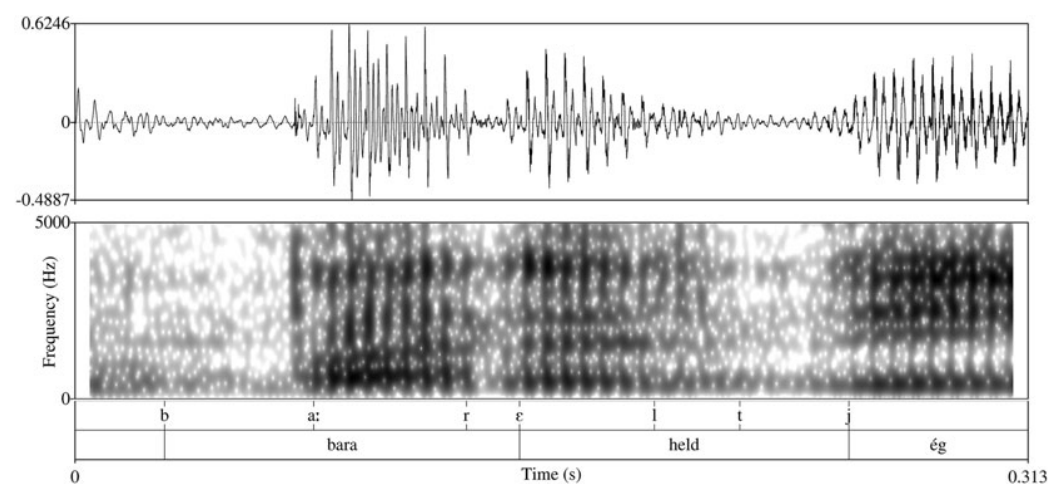

Figure 3. Target sequence: bara held ég; /h/-dropping on held and FVD on bara apply

All remaining $37 \mathrm{CCs}$ were also coded for their syntactic position. Four syntactic positions were considered: (i) clause-final and utterance-final (see (30)); (ii) clause-final but utterance- internal (see (31)); (iii) utteranceinternal and following a syntactic XP (see (32)); (iv) utterance-internal and XP-internal (see (33)).

(30) Position (i): Clause-final and utterance-final (Source: Talmál, Samtöl ÍSTAL)

Speaker B: já sko ${ }_{\mathrm{CP}}\left[\right.$ hann er níutíuogprjú] ${ }_{\mathrm{CP}}[$ held ég]

Speaker A: já

yes so he is ninety-three think I


(31) Position (ii): Clause-final and utterance-internal (Source: Talmál, Samtöl ÍSTAL)

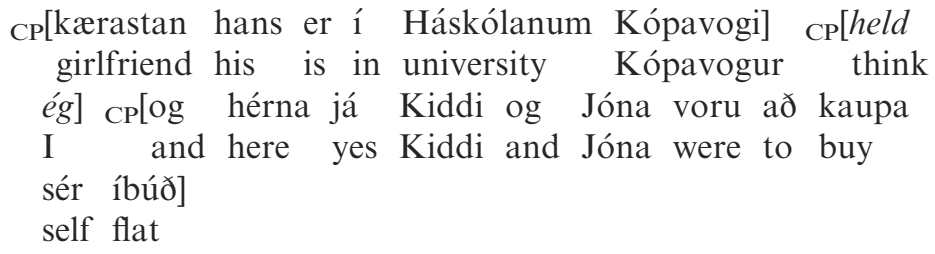

'His girlfriend is at the university in Kópavogur I think and

Kiddi and Jóna bought a flat together.'

(32) Position (iii): Utterance-internal and following a syntactic XP

(Source: Talmál, Samtöl ÍSTAL)

CP[рP[á síðasta ári] ${ }_{\mathrm{CP}}[$ held ég] reyndar...]

on last year think I in.fact

(33) Position (iv): Utterance-internal and XP-internal (Source: Talmál, Samtöl ungs fólks)

CP[pað eru ${ }_{\mathrm{CP}}\left[\right.$ held ég] mörg lönd $\quad{ }_{\mathrm{CP}}[\mathrm{sem}$ purfa að

it are think I many countries that need to

líða fyrir pað]]

suffer for it

Match Clause (see (11)i) predicts prosodic separation of the CC in a non-recursive structure as given in (12)a above for the two clause-final positions in (30) and (31). It predicts prosodic separation of the CC in a recursive structure as given in (12)b and c for the two clause-internal positions in (32) and (33), respectively. In the results section immediately below, the positions are therefore combined accordingly.

\subsection{Results}

As a result of the instrumental analysis described in the previous section, and based on the tonal and segmental cues to intonational phrasing in Icelandic as outlined in Sections 1.2 and 2.1 above, essentially three patterns were found with regard to the phrasing of CC held ég. They are summarised in (34); representative examples for these phrasing patterns are given in (35) through to (37), plotted in Figures 4 through to Figure 6. In Table 2 below, the phrasing results are given according to the position of the $\mathrm{CC}$ in its utterance.

(34) Observed phrasing patterns

a. CC prominent; $\mathrm{N}=3$

${ }_{\mathrm{IP}}\left(\ldots \mathrm{IP}_{\mathrm{IP}}(\text { held ég })_{\mathrm{IP}} \ldots\right)_{\mathrm{IP}}$

b1. CC unstressed; $\mathrm{N}=18$

$<_{\mathrm{IP}}(\ldots)_{\mathrm{IP}}>{ }_{\mathrm{IP}}(\ldots \text { held ég })_{\mathrm{IP}}<_{\mathrm{IP}}(\ldots)_{\mathrm{IP}}>$ 
b2. CC unstressed; $\mathrm{N}=1$ (encliticisation)

$<_{\mathrm{IP}}(\ldots)_{\mathrm{IP}}>{ }_{\mathrm{IP}}\left(\mathrm{IP}(\ldots)_{\mathrm{IP}} \text { held ég }\right)_{\mathrm{IP}}<_{\mathrm{IP}}(\ldots)_{\mathrm{IP}}>$

c. CC unstressed, either pre- or postnuclear; $\mathrm{N}=15$

$\left.<_{\mathrm{IP}}(\ldots)_{\mathrm{IP}}\right)>{ }_{\mathrm{IP}}(\ldots \text { held ég } \ldots)_{\mathrm{IP}}<_{\mathrm{IP}}(\ldots)_{\mathrm{IP}}>$

First, the $\mathrm{CC}$ was prominent with its own pitch accent and phrased in its own prosodic domain (see (34)a; $\mathrm{N}=3$ ). All three CCs realised in this way were in sentence-medial position, and were phrased in a recursive prosodic structure, i.e. according to $(21) \mathrm{b} /(23)$.

An example of this pattern is given in (35)/Figure 4. The CC-verb held is associated with a pitch accent, which is one in a sequence of $\mathrm{L}+\mathrm{H}^{*}$ pitch accents. The hash in the tonal tier in Figure 4 represents a prosodic boundary of a level above the prosodic word. The downward F0 trend is such that the peak associated with máli is higher than the one associated with held, which in turn is higher than the one associated with forseti ('president'), possibly suggesting one long IP. Pitch reset is then observable in the $\mathrm{H}^{*}$ associated with the first syllable of kalla ('call'), not plotted in Figure 4 for space reasons. On the other hand, held ég is clearly set off by boundary markers from the surrounding material: pauses of considerable length on both sides as well as the absence of segmental processes and a pitch fall following the peak associated with held to a low level in the speaker's pitch range, clearly suggesting prosodic separation. The syntactic structure is complex and there are two syntactic interpolations of parenthetical nature, the CC held ég and the vocative hostvirtur forseti ('honorable president'), the latter also being separated from preceding and following material by pauses. The downward $\mathrm{F} 0$ trend seems to provide evidence for a sequence of intermediate phrases, such that the sequence pad skiptir ekki öllu máli ('It does not matter'), the CC held ég and the vocative hosstvirtur forseti all form ips of their own within IP. However, since a prosodic hierarchy has not yet been established for Icelandic, \# indicates a boundary above word level. ${ }^{11}$ Given the prominence associated with the $\mathrm{CC}$, the presence of pauses on both sides and the blocking of segmental processes, (35)/Figure 4 represents a clear case of prosodic separation of the CC.

(35) CC prominent (Source: Talmál, Alpingisumræður)

pað skiptir ekki öllu máli held ég hæstvirtur forseti hvað it divide not all case think I honorable president what menn vilja kalla pað sem að að hér er sett fram men want call it Rel-prn to to here is sit forth 'It does not matter, I think, honorable president, what men want to call what is being put forward here'

\footnotetext{
${ }^{11}$ Alternatively, the downward trend can be seen as evidence for outer IP brackets and a structure along the lines of $\operatorname{IP}\left(\operatorname{IP}(\ldots)_{\mathrm{IP}} \mathrm{IP}(\text { held ég })_{\mathrm{IP}} \operatorname{IP}(\ldots)_{\mathrm{IP}}\right)_{\mathrm{IP}}$. See Myrberg (2013) for a related line of argumentation for Stockholm Swedish, and references given there. I leave this question to future research for Icelandic.
} 


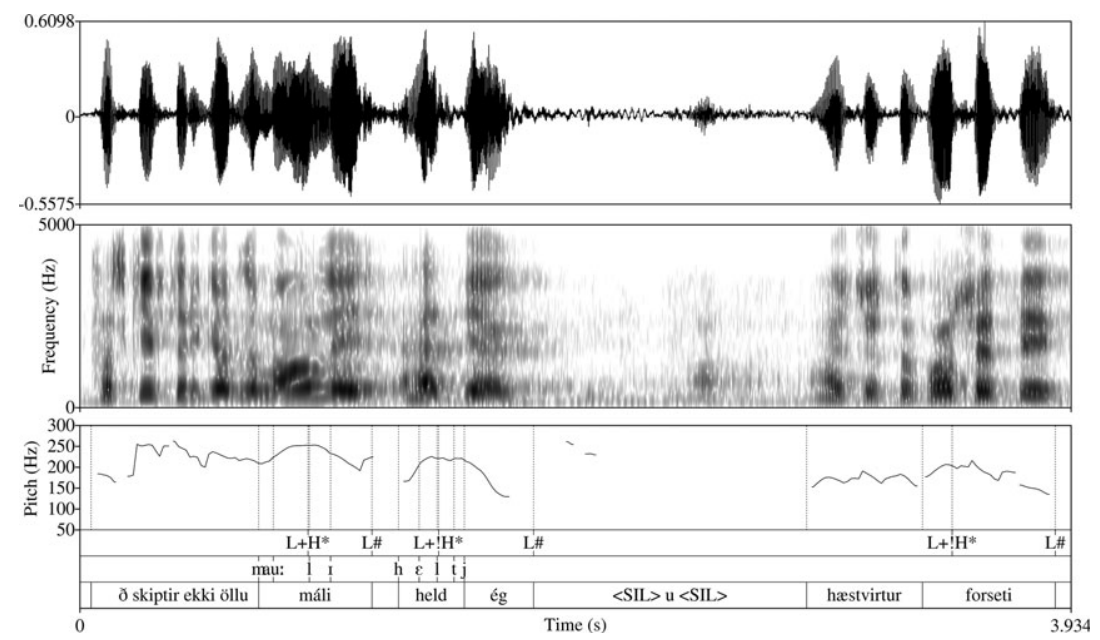

Figure 4. Prosodic separation (pattern (21)b/(34)a)

Second, the CC was non-prominent postnuclear material and as such was phrased in one prosodic domain with preceding host material and followed by an IP boundary $((34) \mathrm{b} 1 ; \mathrm{N}=18)$, i.e. it was phrased according to (24)a. In addition to these 18 items, there was one item which was encliticised to the preceding domain (see (34)b2); the CC was set off from the preceding host material by a boundary tone and pause but was not prominent. Tonally, the CC receives a copy of the preceding tonal targets, i.e. the edge tones (see Gussenhoven 1990, 2004 on encliticisation and tone copy); in the following discussion, this item is subsumed under one phrasing pattern with prosodic integration as in (34)b1/(24)a.

A representative example of pattern (34)b1 is provided in (36)/ Figure 5. The CC is post-nuclear without prominence and final in its IP. Along with the lack of prominence associated with $\mathrm{CC}$, the absence of an IP-boundary between danska and held ég is cued by the application of the segmental process of $/ \mathrm{h} /$-dropping on held as well as tonal cues; dansk $a$ is associated with the nuclear accent of the relevant IP, which is a rise to $\mathrm{H}^{*}$ (masked in Figure 4 by the voiceless plosive onset of danska). From $\mathrm{H}^{*}$ the F0 contour falls towards the low boundary, the second syllable of dansk $a$ and the $\mathrm{CC}$ being associated with this fall. The right edge of the IP is marked by a low boundary tone $\mathrm{L} \%$ and creaky voice. After the boundary tone, there is a step-up in pitch from the low level reached at the end of the IP, not plotted here. Figure 5 zooms in on the IP containing the CC (IP3 in (36)b) for reasons of space. The phrasing pattern including material to the left and right of this stretch of the utterance is given in (36)b. 


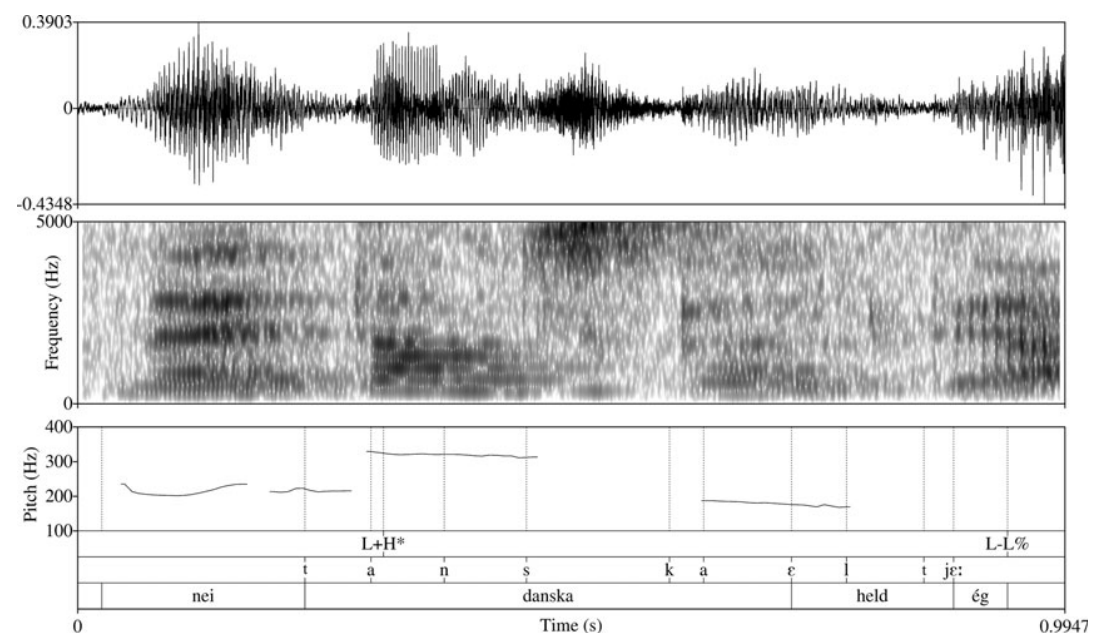

Figure 5. Prosodic integration in IP-final position (pattern (24)a/(34)b1)

(36) CC postnuclear, unstressed, domain-final (Source: Talmál, Samtöl ÍSTAL)

a. svartur maður sem að kom hérna sem á black man Rel-Prn to came here Rel-Prn has danska konu eða íslenska nei danska held ég a Danish woman or Icelandic no Danish think I uh skiptir ekki máli hún er allavega hvít divide not case she is in.any.case white 'A black man, who came here, who has a Danish wife, or Icelandic, no Danish I think, it doesn't matter, she is in any case white'

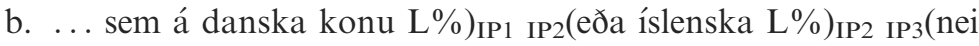
danska held ég L\%) IP3 IP4(a skiptir ekki máli hún er allavega hvít $\mathrm{H} \%)_{\text {IP4 }}$

Third, the CC was without prominence and was preceded and followed in its prosodic domain by host material (see $(34) \mathrm{c} /(24) \mathrm{c})$. It was either part of a prenuclear $(\mathrm{N}=14)$ or a postnuclear $(\mathrm{N}=1)$ string. A representative example is given in (37)/Figure 6; see (27) for its syntactic phrasing. The CC held ég is clearly without prominence and it is placed between two non-nuclear accents associated with hef ('have') and einu (of einu sinni 'once'), respectively. Another cue to the absence of an IP-boundary to the left of the CC is the fact that both $/ \mathrm{h} /-$ dropping (on held) and FVD (on bara) apply. The nuclear accent is associated with skiði ('skiing'). 


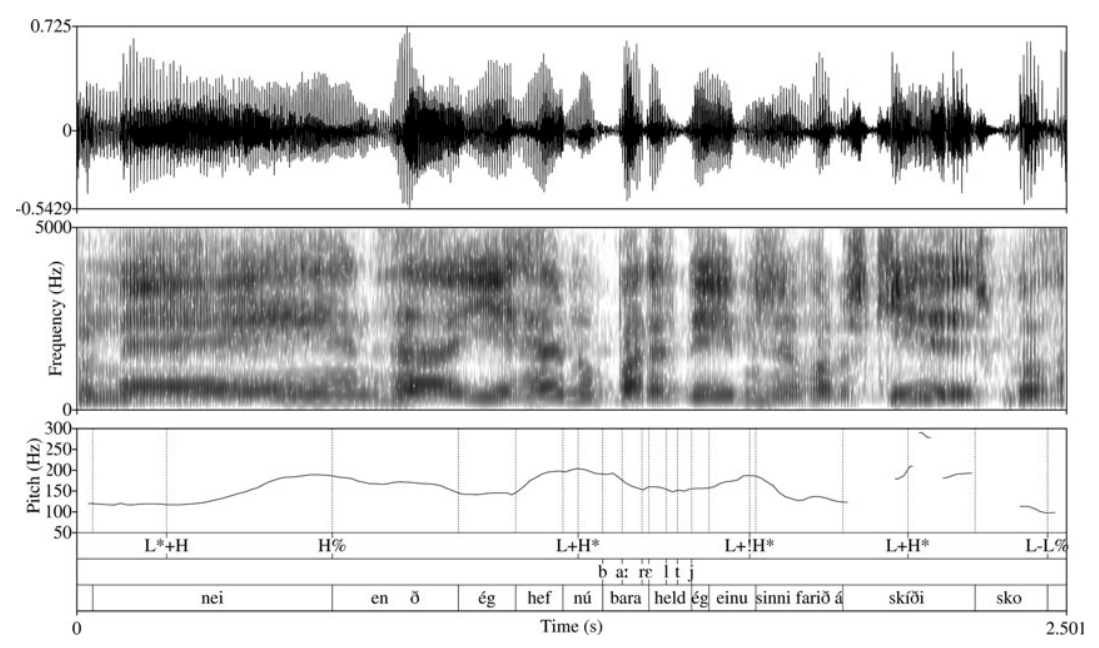

Figure 6. Prosodic integration in IP-medial position (pattern $(24) \mathrm{c} /(34) \mathrm{c})$

(37) CC prenuclear, unstressed, domain-internal (Source: NDC)

... nei en pað ég hef nú bara held ég einu sinni

no but that I have now only think I once

fariðá skíði sko

went on skiing so

'But then I think I only went skiing once, so ...'

Table 2 lists the phrasing results in (34) according to syntactic position. Sixteen CCs were placed in clause final position either at the end of an utterance $(\mathrm{N}=9$; see example (30)) or non-utterance finally ( $\mathrm{N}=7$; see (31)). Twenty-one CCs were placed in clause-medial position either following a syntactic XP (N = 3; see (32)) or XP-internally ( $\mathrm{N}=17$; see (33)).

Table 2. Intonational phrasing of $\mathrm{CC}$ held ég according to syntactic position; clause-final $={ }_{\mathrm{CP}}[$ clause 1$]{ }_{\mathrm{CP}}[\mathrm{CC}]<_{\mathrm{CP}}[$ clause2 $]>$; clause-internal $=$ ${ }_{\mathrm{CP}}\left[\right.$ clause ${ }_{\mathrm{CP}}[\mathrm{CC}]$ clause 1]

\begin{tabular}{|c|c|c|c|c|}
\hline \multirow[b]{2}{*}{$\begin{array}{l}\text { Syntactic position } \\
\text { of CC with respect } \\
\text { to host clause }\end{array}$} & \multicolumn{3}{|c|}{ Attested phrasing; number of occurrences } & \multirow{2}{*}{$\begin{array}{l}\text { Occurrences } \\
\text { overall }\end{array}$} \\
\hline & $\begin{array}{l}(21) \mathrm{b} /(34) \mathrm{a}: \\
\mathrm{IP}(\ldots . \mathrm{IP}(\text { held } \\
\left.\left.e^{\prime}\right)_{\mathrm{IP}} \ldots\right)_{\mathrm{IP}}\end{array}$ & $\begin{array}{l}(24) \mathrm{a} /(34) \mathrm{b}: \\
\mathrm{IP}(\ldots \text { held } \\
\quad \text { ég })_{\mathrm{IP}}\end{array}$ & $\begin{array}{l}(24) \mathrm{c} /(34) \mathrm{c}: \\
\mathrm{IP}(\ldots \text { held } \\
e ́ g \ldots)_{\mathrm{IP}}\end{array}$ & \\
\hline $\begin{array}{l}\text { Clause-final (see } \\
(30) \text { and (31)) }\end{array}$ & 0 & 15 & 1 & 16 \\
\hline $\begin{array}{l}\text { Clause-internal } \\
\text { (see (32) and (33)) }\end{array}$ & 3 & 4 & 14 & 21 \\
\hline Occurrences overall & 3 & 19 & 15 & 37 \\
\hline
\end{tabular}


Overall, CC held ég is most frequently realised without prominence and integrated as prenuclear or postnuclear material in an IP together with host material. Only three CCs were prosodically prominent, all with a nuclear accent and phrased as a separate prosodic constituent.

Two phrasing patterns anticipated in (21) and (24) were not observed in the current data set: prosodic separation of the $\mathrm{CC}$ in a non-recursive structure (see (21)a; but see footnote 11), and phrasing of the CC as in (24)b, with the CC at the left edge of its IP followed by host material in the same IP. An obvious explanation for this is the size of the data set. However, notice that the distributional numbers of observed phrasing patterns are in line with results previously found for English (Dehé 2014; see (13) above), where integration of the $\mathrm{CC}$ as pre- or postnuclear material was the most common pattern like in the present study, and phrasing as in (24)b was very infrequent. It is most striking, perhaps, that none of the CCs following clauses were phrased in their own separate IP. Instead, they were typically integrated with the preceding syntactic clause in one prosodic constituent $(\mathrm{N}=15$ out of 16 , see Table 2$) .^{12}$

\section{Discussion}

It immediately follows from the results presented in the previous section that CCs add to the existing evidence for non-isomorphism between syntactic and prosodic structure. The results are furthermore in line with results reported in previous work for English. They are thus fully in line with Hypothesis I (see (20)I above) that Icelandic CCs, like English ones, exhibit a variety of intonational phrasing patterns. Clearly, prosodic markedness constraints will have to interact with the syntax-phonology interface constraint MATCH CLAUSE (see (11)i) in order to account for the observed patterns. In this section, the observed patterns as given in Table 2 above will be addressed.

Before turning to these cases, it is essential to take another look at the syntax and semantics of CCs as they relate to prosody. Remember the properties of CCs outlined in Section 1. Syntactically, they are parenthetical clauses (Kluck \& de Vries 2015, Griffiths 2015, among others), attached to the host clause as parenthetical adjuncts, involving par-merge, which makes them invisible for the host clause in terms of

\footnotetext{
${ }^{12}$ A reviewer notes that in the Icelandic data set, the CC, if integrated, is never integrated rightwards, i.e. such that it is leftmost in its IP and phrased with host material following the CC ${ }_{\mathrm{IP}}(\mathrm{CC} \ldots)_{\mathrm{IP}}$; compare the pattern in (13)d observed for English). Quite generally speaking, the direction of phrasing changes the semantic scope of the respective $\mathrm{CC}$ over host material. Dehé (2009a:604-605, 2014:39-40) explains a relevant example of English $I$ think. Note that the ${ }_{\mathrm{IP}}(\mathrm{CC} \ldots)_{\mathrm{IP}}$ phrasing pattern was also infrequent in the English data set $(\mathrm{N}=9$ out of 147 ; see (13) above), perhaps suggesting that CCs have scope over preceding material more often than over following material. Given the occurrence but relative infrequency of the ${ }_{\mathrm{IP}}(\mathrm{CC} \ldots)_{\mathrm{IP}}$ phrasing in the English data set, it is likely that it would be found in a larger corpus for Icelandic.
} 
c-command relationships (de Vries 2007, 2012). Being parenthetical clauses, Match Clause predicts them to be matched by an IP in the prosodic structure (Selkirk 2009, 2011). By definition, an IP has at least one accent position, thus a CC matched by an IP has nuclear prominence. Semantically, remember Scheffler's (2009) two-dimensional semantics for CCs. In her view, their primary function is to lower the epistemic threshold, which determines whether the speaker is sure of the proposition, an assumption which has also long been made by other authors noting that $\mathrm{CCs}$ have mitigating functions and evidential meaning (see Section 1 for references). Their secondary contribution, according to Scheffler (2009), is to make a side comment in the domain of conventional implicatures (CIs). Previous work on English already suggests a relation between the prosodic realization of CCs and their meaning (Dehé 2009a, Dehé \& Wichmann 2010, Kaltenböck 2010, Dehé 2014, among others). Dehé (2014) specifically relates the prosodic realization of CCs to Scheffler's (2009) two-dimensional semantics, such that Scheffler's (2009) primary function of lowering the epistemic threshold relates to prosodic integration in terms of phrasing and lack of nuclear prominence, while Scheffler's secondary function, i.e. CI semantics, relates to prosodic separation and prominence. The assumption that CI semantics is related to prosodic separation goes back to Potts (2005) and puts parenthetical CCs with CI semantics in one class with other types of parentheticals such as parenthetical main clauses, non-restrictive relative clauses and nominal appositions.

The relation between prosody and meaning assumed here is illustrated in examples (38), illustrating Scheffler's primary, mitigating function, and (39), illustrating Scheffler's secondary, CI semantics function. In (38), repeated from (36)/Figure 5, the speaker is clearly not sure whether the woman she is talking about is Danish or Icelandic, thus the primary function of the $\mathrm{CC}$ is to lower the epistemic threshold and convey uncertainty on the part of the speaker as to the truth value of the proposition. This function is reflected in prosodic integration and lack of prosodic prominence associated with the CC. In (39), on the other hand, repeated from (35)/Figure 4, there is no reason to assume that the speaker tries to mitigate the proposition of the host clause. The example is taken from a parliamentary debate and the topic being discussed is given different names in the course of the debate. The current speaker underlines that these names should not disguise the real topic. The CC held ég is prominent, reinforcing the side comment, which is that the speaker believes what he says to be true, therefore there is no reason for the epistemic threshold to be lowered. 
(38) CC with mitigating function; non-prominent, postnuclear in IP together with host material (Source: Talmál, Samtöl ÍSTAL)
a. svartur maður sem að kom hérna sem á danska
black man Rel-Prn to came here Rel-Prn has Danish konu eða íslenska nei danska held ég
woman or Icelandic no Danish think I
a skiptir ekki máli hún er allavega hvít
uh divide not case she is in.any.case white

'A black man, who came here, who has a Danish wife, or

Icelandic, no Danish I think, it doesn't matter, she is in any

case white'

(39) CC prominent (Source: Talmál, Alpingisumrceður)

pað skiptir ekki öllu máli held ég hæstvirtur forseti

it divide not all case think I honorable president

hvað menn vilja kalla pað sem að að hér er sett

what men want call it Rel-prn to to here is sit

fram

forth

'It does not matter, I think, honorable president, what men want

to call what is being put forward here.'

Hypothesis III, which holds that meaning is essential because CCs may or may not be prosodically prominent according to their meaning in context, is thus borne out. How does it relate to the prosodic markedness constraints which are in interaction with MATCH CLAUSE to derive the observed pattern? I will make use of an idea related to the constraints Destress-Given and Stress-Focus in Féry \& Samek-Lodovici (2006) (see also Selkirk 2011 for discussion, and references given in both works). Destress-Given states that a discourse-given phrase is prosodically nonprominent, i.e. it prohibits a phrase from carrying phrasal stress prominence. As Selkirk (2011:471) explains, the absence of phrase-level prominence leads to an absence of phrase-level constituent status for a phrase thus marked. This is because another class of constraints, referred to as $\operatorname{Pros} \operatorname{Prom}(\pi)$ by Selkirk (2011) and going back to earlier work, requires that a prosodic constituent $\pi$ be headed, i.e. it must contain a most prominent constituent. If ProsProm(IP) outranks Match Clause, then a clause cannot have constituent status if it is not associated with prominence. For a clause not to be associated with prominence, it must follow a constraint DESTRESS. Since non-prominence in the case of CCs is related to mitigating function, let us call this constraint Destress-Mitig. We also assume a constraint StRESS-CI, which relates to the idea that a phrase with CI semantics must be prosodically prominent. The four constraints relevant at this stage are listed in (40). 
(40) Constraints

a. Syntax-phonology interface constraint Match CLAUSE (Selkirk 2009, 2011):

A clause in syntactic constituent structure must be matched by a corresponding prosodic constituent (i.e., the IP) in phonological representation.

b. Prosodic markedness constraint ProsProm(IP) (Selkirk 2011 and references given there)

An IP must be headed, i.e. it must contain a most prominent constituent.

c. Prosodic markedness constraint Destress-Mitig

A clause whose function is one of mitigation, i.e. to lower the epistemic threshold, which determines whether the speaker is sure of the proposition, is prosodically non-prominent.

d. Prosodic markedness constraint STRESS-CI

A clause with CI semantics is associated with a nuclear accent position.

I will now return to the observed cases (see Table 2) and start with CCs in clause-final position (examples in (30) and (31) above, repeated in (41); square brackets in (41) indicate syntactic clauses). Two phrasing patterns were observed for clause-final CCs, both being patterns of prosodic integration (see Table 2).

(41) CC clause-final

a. CC clause-final and utterance-final já sko ${ }_{\mathrm{CP}}\left[\right.$ hann er níutíuogprjú] ${ }_{\mathrm{CP}}\left[\begin{array}{ll}\text { held } & e ́ g\end{array}\right]$ yes so he is ninety-three think I

b. CC clause-final and utterance-internal ${ }_{\mathrm{CP}}\left[\right.$ kærastan hans er í Háskólanum Kópavogi] ${ }_{\mathrm{CP}}[$ held girlfriend his is in university Kópavogur think ég] ${ }_{\mathrm{CP}}[\mathrm{og}$ hérna já Kiddi og Jóna voru að kaupa I and here yes Kiddi and Jóna were to buy sér íbúð]

self flat

'His girlfriend is at the university in Kópavogur I think and Kiddi and Jóna bought a flat together.'

Table 3 shows how a clause-final CC with CI semantics behaves with respect to the constraints in (40), while Table 4 shows the same for a CC that serves a mitigating function. Underlining indicates main prominence.

In Table 3, all candidates trivially satisfy Destress-Mitig because it does not apply to a CC with CI semantics. Candidates (i) and (ii) satisfy Match clause, but candidate (i) violates ProsProm(IP) because the CCIP has no prominence, and it violates STRESS-CI because the CC with CI semantics is not associated with prominence. Candidates (iii) and (iv) 
both violate MATCh CLAUSE twice, because both the CC and clause1 fail to match an IP in prosodic structure. Candidate (iii) also violates StRESSCI because the CC with CI semantics has no prominence. Note that candidate (iv) satisfies Stress-CI (only) if clausel is associated with prominence; we will assume that prenuclear prominence is realised within clause1. Candidate (ii) wins because it satisfies all three constraints. This case does not occur in the present data set; all CCs with prominence in the present data set are placed in clause-internal position, and all clausefinal CCs are non-prominent and integrated with respect to phrasing.

Table 3. Clause-final CC, CI semantics; underlining indicates main prominence

\begin{tabular}{|c|c|c|c|}
\hline Clause-final CC with CI semantics & StRESS-CI & $\begin{array}{l}\text { ProsProm } \\
\text { (IP) }\end{array}$ & $\begin{array}{l}\text { MATCH } \\
\text { CLAUSE }\end{array}$ \\
\hline (i) ${ }_{\mathrm{IP}}(\underline{\text { clause } 1})_{\mathrm{IP}} \mathrm{IP}(\mathrm{CC})_{\mathrm{IP}}<_{\mathrm{IP}}(\underline{\text { clause } 2})_{\mathrm{IP}}>$ & $* !$ & * & $\sqrt{ }$ \\
\hline 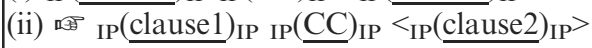 & $\sqrt{ }$ & $\sqrt{ }$ & $\sqrt{ }$ \\
\hline (iii) ${ }_{\mathrm{IP}}(\text { clause1 } \mathrm{C} C)_{\mathrm{IP}} \overline{\overline{\mathrm{IP}}_{\mathrm{IP}}(\text { clause } 2)_{\mathrm{IP}}>}$ & $* !$ & $\sqrt{ }$ & $* *$ \\
\hline$\left(\right.$ iv) ${ }_{\mathrm{IP}}(\overline{\text { clause } 1} \mathrm{CC})_{\mathrm{IP}}<_{\mathrm{IP}}\left(\overline{\text { clause } 2}_{\mathrm{IP}}>\right.$ & $\sqrt{ }$ & $\sqrt{ }$ & $* ! *$ \\
\hline
\end{tabular}

In Table 4, Candidates (i) and (ii) satisfy Match Clause, but candidate (i) violates ProsProm(IP) because the CC-IP has no prominence, and candidate (ii) violates Destress-Mitig because the CC with mitigating function is associated with prominence. Candidates (iii) and (iv) both violate MatCh CLAUSE twice because clause 1 and the CC fail to match IPs in prosodic structure; however candidate (iv) also violates DesTRESSMitig because the $\mathrm{CC}$ with mitigating function is associated with prominence. STRESS-CI is trivially satisfied for the CC because it does not apply to a $\mathrm{CC}$ with mitigating function, and is thus ignored. Candidate (iii) wins if both Destress-mitig and ProsProm(IP) outrank Матсн CLAUSE, although the ranking between the two does not follow from the comparison.

Table 4. Clause-final CC, mitigating semantics; underlining indicates main prominence

\begin{tabular}{|c|c|c|c|}
\hline Clause-final CC with mitigating function & Destress-Mitig & $\begin{array}{l}\text { ProsProm } \\
\text { (IP) }\end{array}$ & $\begin{array}{l}\text { MATCH } \\
\text { CLAUSE }\end{array}$ \\
\hline (i) ${ }_{\mathrm{IP}}(\text { clause1 })_{\mathrm{IP}} \mathrm{IP}(\mathrm{CC})_{\mathrm{IP}}<{ }_{\mathrm{IP}}(\text { clause2 })_{\mathrm{IP}}>$ & $\sqrt{ }$ & $* !$ & $\sqrt{ }$ \\
\hline (ii) ${ }_{\mathrm{IP}}(\text { clause } 1)_{\mathrm{IP}} \mathrm{IP}_{\mathrm{IP}}(\mathrm{CC})_{\mathrm{IP}}<_{\mathrm{IP}}(\underline{\text { clause}})_{\mathrm{IP}}>$ & $* !$ & $\sqrt{ }$ & $\sqrt{ }$ \\
\hline (iii) $\left.\overline{I P}_{\text {(clause1 }} \overline{C C}\right)_{I P}<_{I P}(\overline{c l a u s e})_{I P}>$ & $\sqrt{ }$ & $\sqrt{ }$ & $* *$ \\
\hline$\left(\right.$ iv) ${ }_{\mathrm{IP}}(\text { clause1 } \underline{\mathrm{CC}})_{\mathrm{IP}}<_{\mathrm{IP}}(\text { clause } 2)_{\mathrm{IP}}>$ & $* !$ & $\sqrt{ }$ & $* *$ \\
\hline
\end{tabular}


The interaction of these constraints and their ranking accounts for the fifteen observed cases of prosodically integrated clause-final CCs, as shown in Table 2. Their semantics and intonational phrasing correspond to candidate (iii) in Table 4. Note that the remaining case of clause-final $\mathrm{CC}$ in Table 2, phrased such that material following the $\mathrm{CC}$ is also phrased in the same IP, can be accounted for if the material following the $\mathrm{CC}$ is either discourse-given or has a mitigating function and is therefore without prominence. This turns out to be the case; the respective item is given in (42). The CC is followed by og eitthvad ('or something'), which is without prominence due to its discourse status. This is immediately followed by the end of the turn of the speaker.

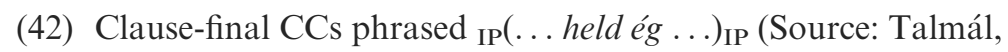
Samtöl ungs folks)

peir ætluðu [pron=mismæli] fóru eitthvað

they intended [pronoun=speech error] went something

til Ástralíu líka held ég og eitthvað

to Australia also think I or something

'I think they also went to Australia or something'

Next, we will account for the intonational phrasing of clause-internal CCs (examples in (32) and (33) above, repeated in (43) for convenience). The observed cases are repeated from Table 2 in (44) below.

(43) CC clause-internal

a. CC clause-internal and following a syntactic XP CP[рP[á síðasta ári] ${ }_{\text {CP}}[$ held $e ́ g]$ reyndar... $]$ on last year think I in.fact

b. CC clause-internal and XP-internal

$$
\begin{aligned}
& \text { СР[pað eru }{ }_{\mathrm{CP}}[\text { held ég] mörg lönd } \mathrm{CP}[\mathrm{sem} \text { purfa að } \\
& \text { it are think I many countries that need to } \\
& \text { líða fyrir pað]] } \\
& \text { suffer for it }
\end{aligned}
$$

(44) Intonational phrasing of clause-internal CCs (repeated from

Table 2)

a. CC phrased according to (21)b/(34)a (prosodic separation in recursive structure)
${ }_{\mathrm{IP}}\left(\ldots \text { IP }(\text { held ég })_{\mathrm{IP}} \ldots\right)_{\mathrm{IP}}$
3 out of 21 cases

b. CC phrased according to (24)a/(34)b (CC phrased with preceding host material)

IP $(\ldots \text { held ég })_{\mathrm{IP}}$

4 out of 21 cases

c. CC phrased according to (24)c/(34)c (CC phrased with preceding and following host material)

$\mathrm{IP}(\ldots \text { held ég ... })_{\mathrm{IP}}$

14 out of 21 cases 
We will once again begin with a CC with CI semantics, which is straightforward (see Table 5). Destress-Mitig is trivially satisfied since it does not apply to CCs with CI semantics and is therefore not considered here. Candidate (ii) satisfies all constraints and is thus the natural winner under any ranking. The $\mathrm{CCs}$ in candidates (iii) and (iv) violate $\mathrm{MATCH}$ CLAUSE because they do not match an IP in prosodic structure. MATCH CLAUSE is violated twice by candidates (v) and (vi), because both the CC and the host clause (clause1) fail to be matched by an IP in prosodic structure. Candidates (iii) and (v) also violate STRESS-CI because the CC with CI semantics does not bear prominence. Candidate (i) violates Stress-CI for the same reason and it also violates ProsProm(IP) because the CC-IP has no prominence. ${ }^{13}$

Table 5. Clause-internal CC, CI semantics; underlining indicates main prominence

\begin{tabular}{|c|c|c|c|}
\hline Clause-internal CC with CI semantics & STRESS-CI & ProsProm(IP) & $\begin{array}{l}\text { MATCH } \\
\text { CLAUSE }\end{array}$ \\
\hline 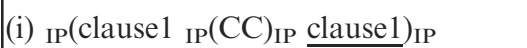 & $* !$ & $*$ & $\sqrt{ }$ \\
\hline (ii) & $\sqrt{ }$ & $\sqrt{ }$ & $\sqrt{ }$ \\
\hline (iii) IP (clause1 CC clause1) $)_{\text {IP }}$ & $* !$ & $\sqrt{ }$ & $*$ \\
\hline$\left(\right.$ iv) ${ }_{\text {IP }}(\text { clause } 1 \text { CC clause1 })_{\text {IP }}$ & $\sqrt{ }$ & $\sqrt{ }$ & $* !$ \\
\hline$\left(\right.$ (v) ${ }_{\text {IP }}\left(\text { clause } 1 \overline{C C}_{\text {IP IP }} \text { (clause } 1\right)_{\text {IP }}$ & $* !$ & $\sqrt{ }$ & $* *$ \\
\hline (vi) ${ }_{\text {IP }}(\text { clause } 1 \text { CC) })_{\text {IP IP }}(\text { clause } 1)_{\text {IP }}$ & $\sqrt{ }$ & $\sqrt{ }$ & $* ! *$ \\
\hline
\end{tabular}

Table 6. Clause-internal CC, mitigating semantics; underlining indicates main prominence

\begin{tabular}{|c|c|c|c|}
\hline $\begin{array}{l}\text { Clause-internal CC with mitigating } \\
\text { function }\end{array}$ & Destress-Mitig & ProsProm(IP) & $\begin{array}{l}\text { MATCH } \\
\text { CLAUSE }\end{array}$ \\
\hline (i) ${ }_{\mathrm{IP}}\left(\right.$ clause $1_{\mathrm{IP}}(\mathrm{CC})_{\mathrm{IP}} \underline{\text { clause } 1)_{\mathrm{IP}}}$ & $\sqrt{ }$ & $* !$ & $\sqrt{ }$ \\
\hline (ii) ${ }_{\mathrm{IP}}\left(\text { clause } 1_{\mathrm{IP}}(\mathrm{CC})_{\mathrm{IP}} \text { clause }\right)_{\mathrm{IP}}$ & $* !$ & $\sqrt{1}$ & $\sqrt{ }$ \\
\hline (iii) ${ }_{\text {IP }}(\text { clause } \overline{C C} \text { clause } 1)_{\text {IP }}$ & $\sqrt{ }$ & $\sqrt{ }$ & * \\
\hline (iv) ${ }_{\mathrm{IP}}(\text { clause } 1 \mathrm{CC} \text { clause1) })_{\mathrm{IP}}$ & $* !$ & $\sqrt{ }$ & * \\
\hline$\left(\right.$ (v) $_{\text {IP }}(\text { clausel } \overline{\mathrm{CC}})_{\text {IP IP }}\left(\underline{\text { clause } 1)_{\text {IP }}}\right.$ & $\sqrt{ }$ & $\sqrt{1}$ & $* *(!)$ \\
\hline$\left(\right.$ (vi) ${ }_{\mathrm{IP}}(\overline{\text { clause }} 1 \mathrm{CC})_{\mathrm{IP}} \mathrm{IP}(\text { clause } 1)_{\mathrm{IP}}$ & $* !$ & $\sqrt{ }$ & $* *$ \\
\hline
\end{tabular}

\footnotetext{
${ }^{13}$ Note that in Tables 5 and 6 , in candidates where clausel is in one IP with an intervening $\mathrm{CC}$, only one part of clause is underlined, because underlining indicates main prominence. In actual speech, prominence in clausel may be realised before or after the $\mathrm{CC}$, depending on the position of the $\mathrm{CC}$ and on the host clause material preceding and following the $\mathrm{CC}$, and there may be more than one prominence position, one of them being the nuclear one. Candidate (iv) in Table 5 satisfies STRESS-CI only if clausel is realised with some (e.g. non-nuclear) prominence because it carries CI-semantics. The same holds for candidate (iv) in Table 6, if STREss-CI is added to the evaluation.
} 
Candidate (ii) in Table 5 corresponds to the three cases of prosodic separation in a recursive prosodic structure observed in the data (see Table 2/(44)a). One of these cases was discussed in (35) and (39) above, explaining intonational phrasing and meaning.

The final case is that of a clause-internal $\mathrm{CC}$ serving a mitigating function. STREss-CI is trivially satisfied for the CC because it does not apply to a CC with mitigating function, and is thus ignored.

In Table 6, Candidates (i) and (ii) satisfy Match Clause, but candidate (i) violates ProsProm(IP) because the CC-IP has no prominence, and candidate (ii) violates Destress-Mitig because the CC with mitigating function is associated with prominence. Candidates (iii) and (iv) both violate Match CLAUSE because the CC fails to match an IP in prosodic structure; however candidate (iv) also violates Destress-Mitig because the $\mathrm{CC}$ with mitigating function is associated with prominence. МАтсH CLAUSE is violated twice by candidates (v) and (vi), because both the CC and the host clause fail to be matched by an IP in prosodic structure. Candidate (vi) also violates Destress-Mitig because the CC with mitigating function bears prominence. Candidates (iii) turns out to be the winner in this competition. Table 2/(44) shows that 14 of 21 cases of clause-internal CCs were phrased in this way.

The remaining four cases not yet accounted for by the tables above were clause-internal CCs phrased according to (44)b. Their realisation corresponds to candidate (v) in Table 6. This candidate behaves worse than the optimal candidate on MATCH CLAUSE (one more violation) but crucially behaves alike on the other constraints, i.e. the prosodic markedness constraints are satisfied. The rating differences between the two candidates, i.e. the optimal candidate (iii) and the suboptimal candidate (v), which follows from the additional violation of МАTCH Clause by candidate (v), is reflected in the number of occurrences in the corpus, with candidate (iii) being much more frequent than candidate (v).

In the remainder of this discussion, and in order to arrive at a more complete picture, we will consider three further prosodic markedness constraints employed in previous research and not yet included in the tables above. They are listed in (45) and addressed immediately below.

(45) Further constraints to be considered

a. EqualSisters (Myrberg 2013)

Sister nodes in prosodic structure are instantiations of the same prosodic category.

b. Egdemost-R(Prom-IP, Edge-IP) (Selkirk 2011 and references given there)

Main prominence is located at the right edge of an IP.

c. *IP (Féry 2011; see her NoPhrase constraint)

Avoid the proliferation of IPs. 
EqualSisters (Myrberg 2013) requires for sister nodes in prosodic structures to be of the same prosodic category, i.e. the sisters of IP should be IPs. It renders the earlier constraints Non-Recursivity and ExhausTIVITY (e.g. Selkirk 1996) redundant and it militates against structures such as (44)a. Depending on the ranking of EQuaLSISTERS, a prosodic structure may be recursive or not. In Myrberg's (2013) work, EQUALSIsTERS interacts with МАTCH to account for the phrasing patterns of coordinated and embedded clauses in Stockholm Swedish. The prosodic structures observed here for Icelandic held ég suggest ranking of Equalsisters below Match Clause. In Tables 3 and 4, with the CC in clause-final position, EQUALSISTERs has no effect because it is satisfied by the respective optimal candidates. ${ }^{14}$ Note incidentally that candidates with recursive phrasing $\left(_{\mathrm{IP}}\left(\ldots \mathrm{IP}_{\mathrm{IP}}(\text { held ég })_{\mathrm{IP}} \ldots\right)_{\mathrm{IP}}\right)$, not given in Tables 3 and 4 above, would violate EqualSisters as well as Match Clause and would thus behave worse than the optimal candidates. In Table 5, the case of clause-internal CC with CI semantics, the optimal candidate violates EqualSisters, while candidates (iii) through to (vi) satisfy it, suggesting evidence for the rank of EQualSisters below Match CLAUSE. In Table 6 (clause-internal CC, mitigating function), the optimal candidate as well as its runner-up satisfy EquALSISTERS, which has thus no effect.

With respect to the location of main prominence within its prosodic constituent, I assume that Egdemost-R(Prom-IP, EDGE-IP) is active at the level of IP in Icelandic since prominence has been shown to be rightmost at phrase- and sentence level in this language (Árnason 1998 among others). If the $\mathrm{CC}$ held ég is prosodically separate and associated with prominence as in Tables 3 and 5, prominence falls onto the verb unless the pronoun has contrastive focus. This can be accounted for along the lines of Destress-Given (Féry \& Samek-Lodovici 2006), since the information conveyed by the pronoun is inherently given. If the CC is clause-final, final in its IP and realised without prominence due to its mitigating function (Table 4), EgDEMOsT-R is violated, but is without effect if outranked by the prosodic markedness constraints DeSTRESSMitig and ProsProm(IP). If the CC is clause-internal, prosodically integrated in medial position in its IP and realised without prominence due to its mitigating function (Table 6), EgDEMOST-R has no effect since main prominence is still rightmost in its IP given that main sentence stress is rightmost in Icelandic.

Finally, NoPhrase "militates against the creation of unnecessary structure" (Féry 2011:1909; see also Truckenbrodt 1999 for a constraint

\footnotetext{
${ }^{14}$ Similar results as for EqualSisters would be obtained throughout for STRONGSTART, which demands that a "prosodic constituent optimally begins with a leftmost daughter constituent which is not lower in the prosodic hierarchy than the constituent that immediately follows" (Selkirk 2011:470).
} 
*P-PHRASE, which seeks to avoid p-phrases altogether, and Prince \& Smolensky's 2004:30 fn. 13 constraint family *STRUC, which bans structure altogether). According to Féry, the formation of prosodic constituents higher in the prosodic hierarchy is worse than that of constituents lower in the hierarchy. In the present context, *IP, which militates against IP-formation, is particularly relevant. The phrasings observed here are supportive of the assumption that *IP is ranked below the interface constraint MAtch Clause. In Table 3, the optimal candidate has two or three (depending on the presence of clause2) *IP violations, while candidates (iii) and (iv) only have one or two (again depending on the presence of clause 2), thus the optimal candidate always has one more *IP violation than candidates (iii) and (iv). However, candidate (iii) violates Stress-CI and Match Clause, and candidate (iv) violates Match Clause. Similarly, in Table 5, the optimal candidate has one more violation of *IP compared to candidates (iii) and (iv). However, candidate (iii) violates Stress-CI and МАтсH Clause, and candidate (iv) violates Match Clause. In Tables 4 and 6, the optimal candidate behaves alike or better on *IP compared to their competitors.

Finally, a reviewer notes - rightly - that STRESS-CI is not needed in Tables 3 and 5. The optimal candidate can be identified as a result of the interaction of ProsProm(IP) and Мatch Clause, none of which is violated by the optimal candidate, while remaining candidates violate either ProsProm(IP) (candidates (i) in Tables 3 and 5) or Match clause (candidates (iii) and (iv) in Table 3 and candidates (iii)-(vi) in Table 5). However, while CCs are clauses and thus subject to Match Clause it is not clear that all elements with CI semantics are clauses in the syntactic structure. Accordingly, Match clause and Stress-CI will have to be separated in the analysis. At the same time, it is clear that while DestressMitig takes care of some rephrasing, non-violation of STRESS-CI results in default phrasing. As suggested by Shin Ishihara (personal communication) it is also conceivable that STRESS-CI can be interpreted as a special instance of (and can thus be replaced by) STRESS-Focus, which demands that a "focused phrase has the highest prosodic prominence in its focus domain" (Féry \& Samek-Lodovici 2006:135). I leave these issues for future research, which will have to include other types of constituents conveying CI semantics and their prosodic realisation.

Overall, the discussion clearly shows that the observed intonational phrasing patterns can be accounted for in terms of the interaction of the syntax-prosody interface constraint MATCH CLAUSE with prosodic markedness constraints, and in particular by ranking Destress-Mitig, ProsProm(IP) and Stress-CI above Match clause, fully in line with Hypothesis II given in (20) above. Based on the current data set, the constraint rankings given in (46) emerge for Icelandic. The relative rankings for constraints separated by commas cannot be established in 
the present context. All other rankings have been established and explained above.

(46) Constraint ranking

a. Destress-Mitig, ProsProm(IP), Stress-CI >> Match clause $>>$ NoPhrase $(*$ IP), EqualSisters

b. Destress-Mitig, ProsProm(IP) $>$ Egdemost-R(Prom-IP, EDGe-IP)

Some open questions remain. For example, more empirical work, based on a larger data set, will have to confirm that mitigating elements are generally non-prominent. For the current Icelandic data set, this correlation holds. However, in the English data reported on in Dehé (2014), there are CCs with nuclear prominence phrased according to (24)a, i.e. prosodically integrated with respect to phrasing, as well CCs with non-nuclear (prenuclear) prominence phrased in one IP with host material along the lines of (24)b-c. Future work will show how those patterns can be accounted for in terms of constraint ranking. Moreover, the semantic division - CI semantics vs. mitigating function - may not always be so clear-cut. I leave these questions to future research.

\section{Summary}

This paper has investigated the prosodic phrasing of the Icelandic parenthetical CC held ég on the basis of data taken from Icelandic spoken language corpora. Three intonational phrasing patterns were observed in the data: (i) the $\mathrm{CC}$ may be phrased in a separate IP in a recursive prosodic structure with nuclear prominence of its own; (ii) it may be non-prominent and followed by an IP-boundary but phrased together in one IP with preceding material; (iii) it may be non-prominent and phrased together with preceding and following material in one IP. Patterns (ii) and (iii), which have in common that the $\mathrm{CC}$ is without prominence and phrased together with host material, are by far more common than prosodic separation of the IP, in line with previous results for English. The observed patterns were accounted for in terms of the interaction of the syntax-prosody interface constraint MATCH CLAUSE with prosodic markedness constraints: ProsProm(IP), which demands that an IP must be headed; Destress-Mitig, which demands that a clause whose function is one of mitigation is prosodically non-prominent; STRESS-CI, which demands that a clause with CI semantics is associated with a nuclear accent position. The ranking of these constraints is such that the prosodic markedness constraints outrank MATCH CLAUSE, although more research is necessary in order to determine the ranking of the prosodic markedness constraints with respect to each other. Other prosodic markedness constraints (NoPhrase $(*$ IP), EqualSisters) are ranked below Match CLAUSE. Future research will verify the claims made here with respect to 
the relation between prominence and meaning, in particular concerning elements with mitigating functions. However, the analysis suggested here does fully account for the current data set and observed phrasing patterns.

\section{References}

Aijmer, Karin. 1997. think - an English modal particle. Modality in Germanic languages: Historical and comparative perspective, eds. T. Swan \& O. Jansen Westvik, 1-47. Berlin \& New York: Mouton de Gruyter.

Árnason, K. 1980. Some processes in Icelandic connected speech. The Nordic Languages and Modern Linguistics [4], ed. E. Hovdhaugen, 212-222. Oslo: Universitetsforlaget.

Árnason, K. 1998. Toward an analysis of Icelandic intonation. Nordic Prosody. Proceedings of the VIIth Conference, Joensuu 1996, ed. S. Werner, 49-62. Frankfurt a.M.: Peter Lang.

Árnason, K. 2005. Hljóð. Handbók um hljóðfraðði og hljóðkerfisfraði. (Vol. 1. Bindi.). Reykjavík: Almenna Bókafélagið.

Árnason, K. 2009. Phonological domains in Modern Icelandic. Phonological Domains: Universals and Deviations. J. Grijzenhout \& B. Kabak, 283-313. Berlin \& New York: Mouton de Gruyter.

Árnason, K. 2011. The Phonology of Icelandic and Faroese. Oxford: Oxford University Press.

BING, J. M. 1985. Aspects of English prosody. New York \& London: Garland.

Boersma, P. 2001. Praat, a system for doing phonetics by computer. GLOT international 5(9-10), 341-345.

Boersma, P. \& Weenink, D. 2012. Praat: doing phonetics by computer [Computer program]. Version 5.3.04; http://www.praat.org/.

BRINTON, L. J. 2008. The comment clause in English: Syntactic origins and pragmatic developments. Cambridge: Cambridge University Press.

Crystal, D. 1969. Prosodic systems and intonation in English. Cambridge: Cambridge University Press.

DenÉ, N. 2008. To delete or not to delete: The contexts of Icelandic final vowel deletion. Lingua 118(5): 732-753.

Dené, N. 2009a. Clausal parentheticals, intonational phrasing, and prosodic theory. Journal of Linguistics 45(3): 569-615.

DeHé, N. 2009b. An intonational grammar for Icelandic. Nordic Journal of Linguistics 32(1): 5-34.

DEHÉ, N. 2010. The nature and use of Icelandic prenuclear and nuclear pitch accents: Evidence from F0 alignment and syllable/segment duration. Nordic Journal of Linguistics 33(1): 31-65.

Dené, N. 2014. Parentheticals in Spoken English: The Syntax-Prosody Relation. Cambridge: Cambridge University Press.

Dehé, N. \& Wichmann, A. 2010. The multifunctionality of epistemic parentheticals in discourse: prosodic cues to the semantic-pragmatic boundary. Functions of Language 17(1): 1-28.

DE VRIES, M. 2007. Invisible constituents? Parentheses as B-merged adverbial phrases. Parentheticals [Linguistik Aktuell/Linguistics Today 106], eds. N. Dehé \& Y. Kavalova, 203-234. Amsterdam: John Benjamins.

DE VRIES, M. 2012. Unconventional Mergers. Ways of Structure Building, ed. M. Uribe-Etxebarria \& V. Valmala, 143-166. Oxford: Oxford University Press.

Einarsson, S. 1973. Icelandic: Grammar, texts, glossary. 2nd ed. Baltimore: The John Hopkins University Press. 
FÉRY, C. 2011. German sentence accents and embedded prosodic phrases. Lingua 121(13): 1906-1922.

Féry, C. \& SAmeK-Lodovici, V. 2006. Focus projection and prosodic prominence in nested foci. Language 82(1): 131-150.

Fortmann, C. 2007. The complement of reduced parentheticals. Parentheticals [Linguistik Aktuell/Linguistics Today 106], eds. N. Dehé \& Y. Kavalova, 89119. Amsterdam: John Benjamins.

Fraser, B. 1980. Conversational mitigation. Journal of Pragmatics 4(4): 341-350. Griffiths, J. 2015. Parenthetical verb constructions, fragment answers, and constituent modification. Natural Language \& Linguistic Theory 33: 191-229.

GunNarsdótTir, S. 2012. Sérhljód og breytileiki peirra. Rannsókn á formendatiððni langra og stuttra einhljóda í íslensku. M.A. Thesis, Háskóli Íslands.

Gussenhoven, C. 1990. Tonal association domains and the prosodic hierarchy in English. Studies in the pronunciation of English. A commemorative volume in honour of A. C. Gimson, ed. S. M. Ramsaran, 27-37. London: Routledge.

Gussenhoven, C. 2004. The phonology of tone and intonation. Cambridge: Cambridge University Press.

Hand, M. 1993. Parataxis and parentheticals. Linguistics and Philosophy 16: 495507.

Helgadóttir, S., Svavarsdóttir, Á., Rögnvaldsson, E., Buarnadóttir, K. \& Loftsson, H. 2012. The Tagged Icelandic Corpus. Proceedings of the Workshop on Language Technology for Normalisation of Less-Resourced Languages (SaLTMiL 8-AfLaT2012), Istanbul, Turkey, eds. G. de Pauw, G.-M. de Schryver, M.L. Forcada, K. Sarasola, F.M. Tyers \& P.W. Wagacha, 67-72.

Helgason, P. 1993. On coarticulation and connected speech processes in Icelandic. Malvisindastofnun Háskóla Íslands, Reykjavík

JACKENDOFF, R. 1972. Semantic interpretation in generative grammar. Cambridge, MA: MIT Press.

Johannessen, J., Priestley, J., Hagen, K., Åfarli, T. \& Vangsnes, Ø. 2009. The Nordic Dialect Corpus - an advanced research tool. Proceedings of NODALIDA 2009, eds. K. Jokinen \& E. Bick, Odense, Denmark, 73-80.

Kaltenböck, G. 2010. Pragmatic functions of parenthetical I think. New Approaches to Hedging, eds. G. Kaltenböck, W. Mihatsch \& S. Schneider, 243-270. Bingley: Emerald.

KärkKäInEn, E. 2003. Epistemic stance in English conversation: A description of its interactional functions, with a focus on I think. Amsterdam: John Benjamins.

KluCK, M. \& DE VRIES, M. 2015. On V2, gaps, and operators in comment and reporting parentheticals. Parenthetical Verbs, eds. S. Schneider, J. Glikman \& M. Avanzi, 103-134. Berlin: De Gruyter.

Miтtwoch, A. 1979. Final parentheticals with English questions - their illocutionary function and grammar. Journal of Pragmatics 3: 401-412.

Murphy, M. L. 1993. Discourse markers and sentential syntax. Studies in the Linguistic Sciences 23(1): 163-167.

Myrberg, S. 2013. Sisterhood in prosodic branching. Phonology 30(1): 73-124.

Nespor, M. \& Vogel, I. 1986. Prosodic Phonology [Studies in Generative Grammar 28)]. Dordrecht: Foris.

Peters, J. 2006. Syntactic and prosodic parenthesis. Proceedings of the International Conference on Speech Prosody. 2-5 May 2006, Dresden.

Pоттs, C. 2002. The syntax and semantics of as-parentheticals. Natural Language \& Linguistic Theory 20(3): 623-689.

PotTs, C. 2005. The Logic of Conventional Implicatures. Oxford: Oxford University Press. 
Prince, A. \& Smolensky, P. 2004. Optimality Theory: Constraint Interaction in Generative Grammar. Oxford: Blackwell.

Quirk, R., Greenbaum, S., Leech, G. \& Svartvik, J. 1985. A Comprehensive Grammar of the English Language. New York: Longman.

ReIs, M. 1995. Wer glaubst du hat recht? On so-called extractions from verbsecond clauses and verb-first parenthetical constructions in German. Sprache und Pragmatik 36: 27-83.

ReIs, M. 2002. Wh-movement and integrated parenthetical constructions. Studies in Comparative Germanic Syntax, eds. C. J.-W. Zwart \& W. Abraham, 3-40. Amsterdam: John Benjamins.

RoORYCK, J. 2001. Evidentiality, Part I. GLOT international 5(4): 125-133.

Ross, J. R. 1973. Slifting. The formal analysis of natural languages, eds. M. Gross, M. Halle \& M.-P. Schützenberger, 133-169. The Hague, Paris: Mouton.

Scheffler, T. 2009. Evidentiality and German attitude verbs. University of Pennsylvania Working Papers in Linguistics 15(1): 183-192.

SCHNeIDER, S. 2007a. Reduced parenthetical clauses as mitigators: A corpus study of spoken French, Italian and Spanish. Amsterdam: John Benjamins.

SchneIder, S. 2007b. Reduced parenthetical clauses in Romance languages: A pragmatic typology. Parentheticals [Linguistik Aktuell/Linguistics Today 106], eds. N. Dehé \& Y. Kavalova, 237-258. Amsterdam: John Benjamins.

SElkiRK, E. 1996. The prosodic structure of function words. Signal to Syntax: Bootstrapping from Speech to Grammar in Early Acquisition, eds. J. Morgan \& K. Demuth, 187-213. Mahwak, NJ: Lawrence Erlbaum.

SELKIRK, E. 2009. On clause and intonational phrase in Japanese: The syntactic grounding of prosodic constituent structure. Gengo Kenkyu 136: 35-73.

SELKIRK, E. 2011. The syntax-phonology interface. The Handbook of Phonological Theory (2nd edition), ed. J. Goldsmith, J. Riggle \& A.C.L. Yu, 435-484. Oxford: Wiley-Blackwell.

SteinBACH, M. 2007. Integrated parentheticals and assertional complements. Parentheticals [Linguistik Aktuell/Linguistics Today 106], eds. N. Dehé \& Y. Kavalova, 53-87. Amsterdam: John Benjamins.

Thompson, S. A. \& Mulac, A. 1991. A quantitative perspective on the grammaticization of epistemic parentheticals in English. Approaches to Grammaticalization, eds. E. Traugott \& B. Heine, 313-327. Amsterdam: John Benjamins.

Thráinsson, H. 1986. V1, V2, V3 in Icelandic. Verb Second Phenomena in Germanic Languages, eds. H. Haider \& M. Prinzhorn, 169-194. Foris: Dordrecht.

Thráinsson, H., Angantýsson, Á., Svavarsdóttir, Á., Eythórsson, T. \& Jónsson, J.G. 2007. The Icelandic (Pilot) Project in ScanDiaSyn. Nordlyd 34: 87-124.

Truckenbrodt, H. 1999. On the relation between syntactic phrases and phonological phrases. Linguistic Inquiry 30(2): 219-255.

TRUCKEnBRODT, H. 2005. A short report on intonation phrase boundaries in German. Linguistische Berichte 203: 273-296.

Urmson, J. O. 1952. Parenthetical verbs. Mind 61: 480-496.

Nicole Dehé

Universität Konstanz

FB Sprachwissenschaft Fach 186

78457 Konstanz Germany

nicole.dehe@uni-konstanz.de 